\title{
Geoarchaeology of the Cobrinhos site (Vila Velha de Ródão, Portugal) - a record of the earliest Mousterian in western Iberia
}

\author{
Telmo Pereira ${ }^{\mathrm{a}, *}$, Pedro P. Cunha ${ }^{\mathrm{b}}$, António A. Martins ${ }^{\mathrm{c}}$, David Nora ${ }^{\mathrm{a}}$, Eduardo Paixão ${ }^{\mathrm{a}, \mathrm{d}}$, \\ Olívia Figueiredo $^{\mathrm{e}}$, Luis Raposo ${ }^{\mathrm{f}}$, Francisco Henriques ${ }^{\mathrm{e}}$, João Caninas ${ }^{\mathrm{e}}$, Delminda Moura ${ }^{g}$, \\ David R. Bridgland ${ }^{\mathrm{h}}$
}

\author{
${ }^{a}$ ICArEHB - Interdisciplinary Center for Archaeology and Evolution of Human Behaviour, Faculdade de Ciências Humanas e Sociais, Universidade do Algarve, Campus \\ Gambelas, 8005-139 Faro, Portugal \\ ${ }^{\mathrm{b}}$ MARE - Marine and Environmental Sciences Centre; Department of Earth Sciences, University of Coimbra, Portugal \\ ' ICT - Instituto de Ciências da Terra, Departamento de Geociências, Universidade de Évora, Rua Romão Ramalho, 59, 7000-671 Évora, Portugal \\ ${ }^{\mathrm{d}}$ Laboratory for Traceology and Controlled Experiments (TraCEr), MONREPOS - Archaeological Research Centre and Museum for Human Behavioural Evolution, RGZM, \\ Germany \\ ${ }^{\mathrm{e}}$ EMERITA - Empresa Portuguesa de Arqueologia, Uni. Lda, Apartado 32 - BEC Oeiras, 2781-901 Oeiras, Portugal \\ ${ }^{\mathrm{f}}$ MNA - Museu Nacional de Arqueologia, Praça do Império, 1400-206 Lisboa, Portugal \\ ${ }^{g}$ CIMA - Centro de Investigação Marinha e Ambiental, Faculdade de Ciências e Tecnologia, Universidade do Algarve, Campus de Gambelas, 8005-139 Faro, Portugal \\ ${ }^{\mathrm{h}}$ Department of Geography, Durham University, South Road, Durham DH1 3LE, UK
}

\section{A R T I C L E I N F O}

\section{Keywords:}

Mousterian

Middle Palaeolithic

Neanderthals

Fluvial terraces

River Tejo

Iberian Peninsula

\begin{abstract}
A B S T R A C T
Cobrinhos (Vila Velha do Ródão, central eastern Portugal) is a Mousterian site found during factory construction in 2014. This area is located in the Lower Tejo valley, which is characterized in terms of geomorphology by six river terraces, numbered downwards (T1 to T6), with Palaeolithic industries associated only with T4 to T6. Terrace T4 was recently dated as spanning ca. $340 \mathrm{ka}$ to $155 \mathrm{ka}$, with Acheulean in the basal and middle levels and early Mousterian in the uppermost levels. The geological context at Cobrinhos is a colluvial unit that links to the top of T4. It has evidence for palaeoweathering with the same characteristics as seen in T1 to T4, considerably different from that seen in T5 and T6. Despite disturbance by ploughing, the site shows a uniform distribution of sizes and shapes of lithic artefacts, with thousands of implements $<30 \mathrm{~mm}$ and a coherent Mousterian assemblage including Levallois and discoidal reduction pieces, Levallois flakes, blades and points, pseudo-Levallois points, notches, denticulates, sidescrapers, and an absence of Acheulean or Upper Palaeolithic tools. The available data suggest that the colluvial unit is coeval with the topmost T4 deposits and that the Cobrinhos industry is in its original geomorphological context. Although the colluvial unit cannot be dated directly, from the combination of site data and available published luminescence ages for T4, we suggest a probable age of ca. 165 to $155 \mathrm{ka}$ for this industry. These results are of relevance in the investigation of the demise of archaic Pleistocene human populations and the proliferation of Neanderthal groups in Iberia.
\end{abstract}

\section{Introduction}

\subsection{The Middle Palaeolithic in western Eurasia}

The Middle Palaeolithic of Iberia has received considerable attention in recent times in connection with the extinction of the Neanderthals (e.g.; Bicho et al., 2015; Bradtmöller et al., 2012; De la Peña, 2013; Finlayson et al., 2006, 2008; Galván et al., 2014; Jöris et al., 2003; Zilhão, 1993, 2000, 2006, 2009; Zilhão et al., 2010, 2017), but is also relevant in connection with the early establishment of the Mousterian, the diversity and demise of early archaic human forms and the widespread distribution of the first Neanderthals (Álvarez-Alonso, 2014; Daura et al., 2017; Ollé et al., 2013; Santonja et al., 2016; Santonja and Pérez-González, 2006; Terradillos-Bernal and DíezFernández-Lomana, 2012).

The beginning of the Middle Palaeolithic in western Eurasia

\footnotetext{
* Corresponding author.

E-mail addresses: telmojrpereira@gmail.com (T. Pereira), pcunha@dct.uc.pt (P.P. Cunha), aam@uevora.pt (A.A. Martins), david.ac.nora@gmail.com (D. Nora), paixao@rgzm.de (E. Paixão), oliviaffigueiredo@gmail.com (O. Figueiredo), 3raposos@sapo.pt (L. Raposo), fjrhenriq@gmail.com (F. Henriques), emerita.portugal@gmail.com (J. Caninas),dmoura@ualg.pt (D. Moura),d.r.bridgland@durham.ac.uk (D.R. Bridgland).
} 
corresponds, in general terms, to a gradual (but not linear) replacement of handaxes and cleavers by pre-determined blank production, especially Levallois (Boëda, 1994, 1993; Boëda et al., 1990; Bordes, 1980, 1971, 1961, 1953; Bourguignon, 1997; Dibble and Bar-Yosef, 1995; McPherron, 1994; Mourre, 2003; Tixier et al., 1980). Early evidence of changes towards the Middle Palaeolithic appears through western Europe back to Marine Isotope Stage (MIS) 11 (424 to 374 ka; Lisiecki and Raymo, 2005), but unequivocal Levallois occurs only during MIS 9 (337 to $300 \mathrm{ka}$ ) and the MIS 9-8 transition (Adler et al., 2014; ÁlvarezAlonso, 2014; Bridgland et al., 2013; Bridgland and White, 2014; Carmignani et al., 2017; de la Torre et al., 2013; Picin et al., 2013; Santonja et al., 2016; Schreve et al., 2002; Soriano and Villa, 2017; Westaway et al., 2006; White et al., 2006).

We believe that the first Neanderthal populations in Iberia immigrated via the Pyrenees. The earliest evidence of Middle Palaeolithic comes from eastern Spain, namely from Atapuerca TD10, dated between 400 and 300 ka (Berger et al., 2008; Falguères et al., 1999; Fernández Peris et al., 2008; Ollé et al., 2013; Rodríguez, 2004). No evidence of handaxes was found but sidescrapers, denticulates and Levallois artefacts were found, dating from 347 to 242 ka (Fernández Peris et al., 2008). The main rivers of the region must have worked as preferential pathways of penetration and dispersal, the Tejo/Tajo (Tagus in English) possibly being one of the most useful due to its length and width and as it crosses Iberia from the east to the western Atlantic coast. As a result, it passes through different geographic settings and landscapes, which may have favoured the creation of ecological niches with abundant and diverse resources capable of supporting long-term human occupation, even during periods with the harshest and coldest conditions (Dennell et al., 2011; González-Sampériz et al., 2010; Rodrigues et al., 2011; Voelker et al., 2017).

In the Spanish sector of the Middle River Tejo, the first evidence of Mousterian occurs in the middle deposits of terrace T19, alongside Acheulean, but the Acheulean disappears in the upper deposits (Laplana et al., 2015; Panera et al., 2011; Silva et al., 2017, 2013). Mousterian without Acheulean also occurs within the sequences of T20 and T21 (Arsuaga Ferreras and Aguirre Enríquez, 1979; Panera et al., 2014; Rubio-Jara et al., 2016; Silva, 2003; Yravedra et al., 2012). In Portugal, the record is patchy; however, recent investigation in the Lower Tejo proved that the river terrace staircases there are important archives for the interpretation of human occupation during the Pleistocene, including the record of the Lower to Middle Palaeolithic transition that occurs within the sediments of the T4 terrace, probably at ca. $220 \mathrm{ka}$ (Cunha et al., 2017b, 2017a, 2016).

\subsection{Previous research on the Palaeolithic in the Lower Tejo}

In the Lower Tejo, investigation focused on the identification of lithic industries began in the 19th century, leading to the identification of Lower Palaeolithic to Mesolithic sites (Cartailhac, 1886; Choffat, 1884; Corrêa, 1928, 1926; Costa, 1865; Delgado, 1901; Ribeiro, 1867, $1866,1880,1873 b, 1873 a, 1871)$. Near the coast, Furninha and Moura caves revealed Pleistocene lithic artefacts, fauna and human remains (Delgado, 1884, 1867). Between the 1930s and 1960s, the production of the 1/50,000 Portuguese geological maps allowed the identification of multiple sites, some with stratigraphy (Breuil and Zbyszewski, 1945; Cunha et al., 2017a; Raposo and Cardoso, 2000; Zbyszewski, 1943, 1946, 1954, 1958, 1966, 1977; Zbyszewski and Breuil, 1943), while the National Archaeological Museum team excavated many Upper Palaeolithic sites in the flint-rich region of Rio Maior (Heleno, 1965; Zilhão, 1997). From the 1970s to the 1980s, the construction of the Fratel dam led to the discovery of rock art and Palaeolithic sites in stratigraphical setting in the Ródão area (Lower Tejo reach I), some with excellent preservation conditions, namely at Monte Famaco (Raposo, 1996; Raposo et al., 1993; Silva et al., 1975), Vilas Ruivas (G.E.P.P., 1983, 1980; Raposo and Silva, 1982, 1981) and Foz do Enxarrique (G.E.P.P., 1977; Raposo et al., 1985; Raposo and Brugal, 1999). Later, mandatory
Cultural Resources Management (CRM) activity, related to construction projects, exposed Mousterian sites in the Lower Tejo at Estrada do Prado (Mateus, 1984), Santa Cita (Bicho and Ferring Reid, 2001; Lussu et al., 2001), Conceição (Raposo and Cardoso, 1998) and Campo de Futebol de Santo Antão do Tojal (Figueiredo et al., 2005). From the 1990s onwards, investigation at the right-bank margin of the Lower Tejo has revealed Pleistocene contexts, especially in the long-timescale sequence at the Ribeira da Atalaia site (e.g. Grimaldi and Rosina, 2001).

In Columbeira, Suão and Salemas caves, all located in the western face of the nearby Estremenho Limestone Massif ( $>130 \mathrm{~km}$ towards the west) and discovered during the exploitation of quarrying, were found rich lithic Mousterian assemblages along with fauna and, at Columbeira, Pleistocene human remains (da Ferreira, 1966, 1984; Roche, 1973; Roche et al., 1962, 1961; Roche and da Veiga Ferreira, 1970; Zbyszewski et al., 1961). From the 1980s onwards, the Caldeirão cave (Zilhão, 1997, 1992), the Almonda karst system (Zilhão et al., 1993, 1990) and Picareiro cave (Bicho et al., 2000) yielded Palaeolithic data, including abundant fauna and human remains.

In summary, the concentration of Palaeolithic sites in the Lower Tejo basin and nearby areas (e.g. the Estremenho Limestone Massif), particularly in the relatively small area of Ródão, provides scope for geomorphological and sedimentological studies, absolute dating of the deposits, and stone-tool analysis, enabling the integration of data obtained from the sedimentary records with archaeological data. This combination supports the reconstruction of local palaeoclimate, palaeoenvironment, palaeolandscape and stone-tool characteristics, with a view to shedding light on human behaviour.

The aim of this paper is to present results of the geomorphological, sedimentological and archaeological investigations carried out at Cobrinhos, in order to provide an improved understanding of the Middle Palaeolithic human occupation and resource exploitation here, as well as environmental conditions during the Middle to Late Pleistocene of westernmost Iberia.

\subsection{The Lower Tejo terraces}

River terrace systems are amongst the best archives for the reconstruction of Pleistocene palaeoclimate, palaeoenvironment and palaeolandscape, as well as human behaviour (Bridgland and Westaway, 2008; Bridgland, 2000; Bridgland and Maddy, 2002; Chauhan et al., 2017; Daveau, 1993, 1980; Martins et al., 2017; Martins and Cunha, 2009; Mishra et al., 2007). The sedimentary records of the Tejo allow the geological evolution of this river to be traced back to ca. $4 \mathrm{Ma}$ (Cunha, 1996, 1992; Cunha et al., 2017b, 2016, 1993; Cunha and Martins, 2004, 2000; Martins et al., 2009; Martins and Cunha, 2009; Silva et al., 2017) and provide a large number of archaeological sites in the Spanish (High and Middle Tajo) and Portuguese (Lower Tejo) sectors (e.g. Raposo, 1995; Raposo et al., 1993; Raposo and Santonja, 1995; Santonja and Pérez-González, 2010; Santonja and Villa, 1990;).

The uppermost reach of the Lower Tejo (Portuguese Reach I) coincides with the Vila Velha de Ródão - Feia/Remédios and Arneiro - Vilas Ruivas depressions. The stratigraphic units that record the evolution of the Lower Tejo have different sedimentary characteristics and lithic industries (e.g. Cunha et al., 2016). The oldest geological bedrock units comprise the Neoproterozoic and Lower Cambrian schists and metagreywackes of the Beiras Group (e.g. Romão, 2001) and the Ordovician Armorican Quartzite Formation (Metodiev et al., 2009; Lobarinhas et al., 2010). The latter forms resistant ridges that topographically dominate the very extensive adjacent planation surface. The Cenozoic is represented by the Cabeço do Infante, Silveirinha dos Figos and Falagueira formations, all with predominant soft sandstones and gravels (Cunha, 1992, 1996). The Late Pliocene and Pleistocene record is summarized as follows (Cunha et al., 2012): (i) a culminant sedimentary unit, termed USB13, with an age of 4-1.8 Ma and corresponding with ancestral River Tejo sediments that cap the Cenozoic basin-fill, laid down shortly before the drainage network started to become 

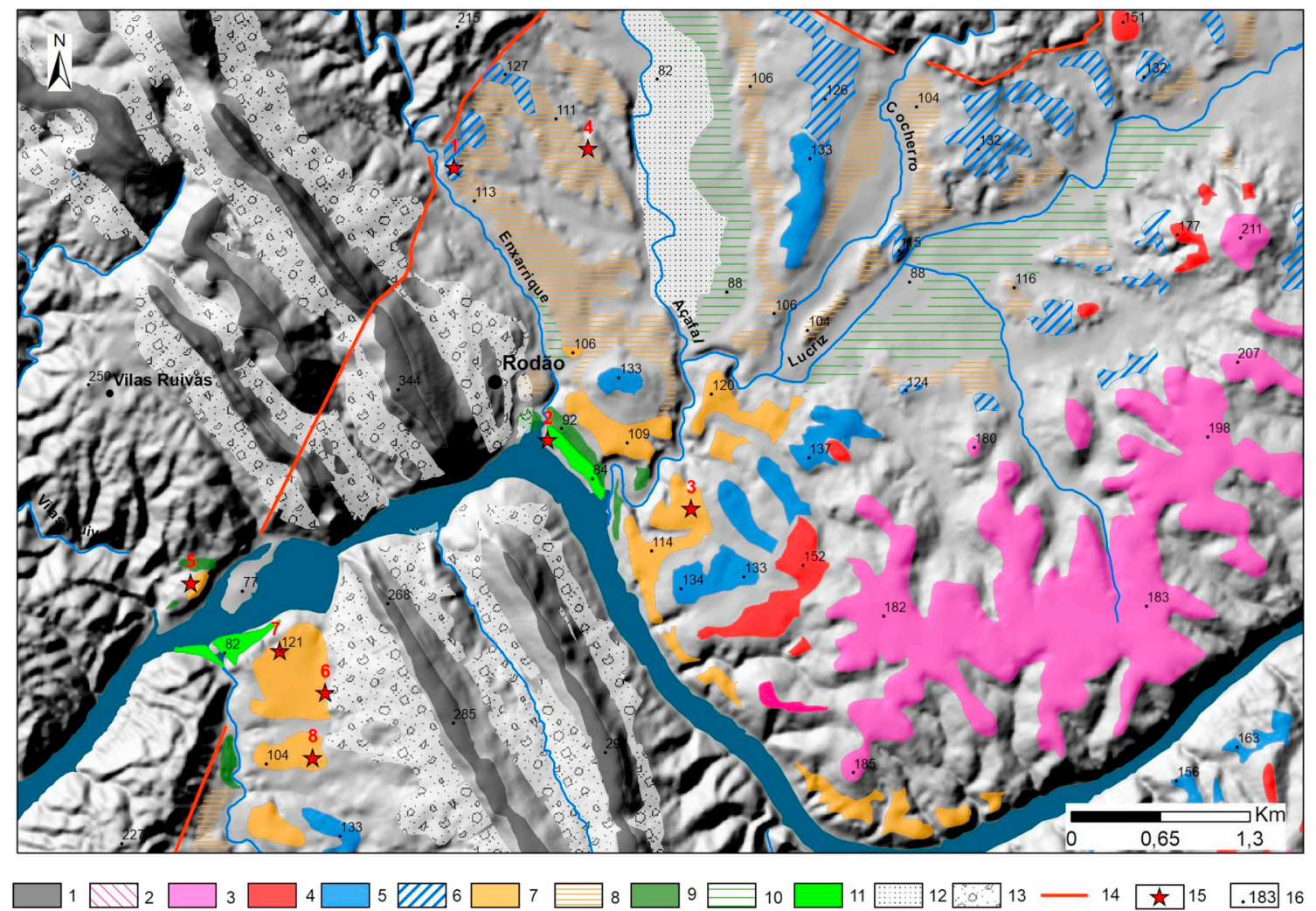

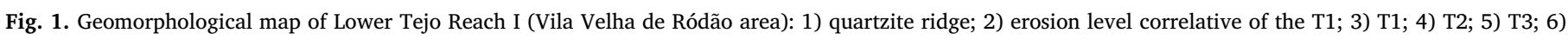

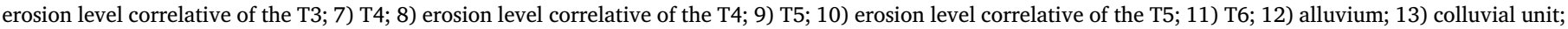

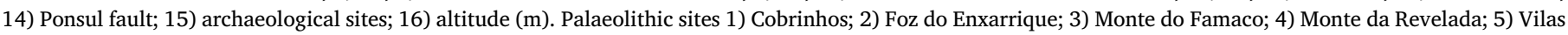
Ruivas; 6) Tapada do Montinho; 7) Pegos do Tejo; 8) Arneiro.

entrenched, without artefacts; (ii) T1 (ca. 1000?-900 ka), without artefacts; (iii) T2 (top deposits ca. 600 ka), without artefacts; (iv) T3 (ca. 460-360? ka), without artefacts; (v) T4 (ca. 340-155 ka), with Acheulean in the basal and middle levels and Mousterian in the uppermost levels; (vi) T5 terrace (135-73 ka), with Mousterian throughout the sequence; (vii) T6 terrace (62-32 ka), also with Mousterian throughout the sequence; (viii) Carregueira Sands (aeolian sands) (32 to $12 \mathrm{ka}$ ), with Upper Palaeolithic to Epi-Palaeolithic; (xix) the floodplain (ca. 12 ka to Holocene), with Mesolithic and more recent industries.

In general, the terrace deposits are composed of massive clast-supported boulder gravels of sub-rounded to rounded quartzite $(\geq 75 \%)$ pebbles, poorly to moderately sorted and packed out by a coarse sand to silt quartz matrix. The T5 and T6 terraces have upper parts comprising sandy-silts, ca. 4 to $5 \mathrm{~m}$-thick. At Foz do Enxarrique, the T6 terrace has some thin levels of pedogenic calcareous concretions and a bed containing faunal remains (e.g. Cunha et al., 2008) (Fig. 1, Fig. 2; Supplementary Information 1: Table 1).

\subsection{The Cobrinhos site}

The Cobrinhos site is located close to the northern margin of Lower Tejo Reach I, in the left side of the confluence area of the Enxarrique stream, a minor right-bank tributary of the Tejo, this location being immediately upstream of the Portas do Ródão ridges, at Vila Velha de Ródão (Fig. 3a and b). The site was found in the autumn of 2014, during work related to the enlargement of a factory (Henriques, 2015). Although the developer performed all the mandatory procedures, the site was not detected by any archaeological work (Albergaria, 2014; Carvalho, 2014; Jacinto, 2008a, 2008b). It was only during westward enlargement of the original building that a high concentration of
Mousterian stone tools was recognized, scatted on the surface (Henriques, 2015) (Fig. 3c).

Preliminary results showed that (1) stone-tools were concentrated in an area of ca. $1600 \mathrm{~m}^{2}$, corresponding with a superficial shallow layer between 15 and $40 \mathrm{~cm}$ that was heavily disturbed by ploughing down to a maximum depth of $40 \mathrm{~cm}$, (2) the assemblage was congruent with the Mousterian, with discoidal and Levallois production, (3) there were large numbers of flakes $<3 \mathrm{~cm}$, all homogeneously slightly patinated, and (4) artefacts typical of the Lower or Upper Palaeolithic were absent. Based on this, we concluded that, despite the absence of an "archaeological Pompeii" scenario, (1) the assemblage was well delimited in area and depth, (2) it was rich, culturally homogeneous and with considerable technological integrity and, therefore, (3) it promised a significant contribution to the characterization of the Middle Palaeolithic.

\section{Materials and methods}

The development in which the Cobrinhos site was found occurred during the Portuguese economic crisis and this circumstance deeply affected the procedures, as the village is one of the poorest of the country. Under rainy conditions, a team of five people undertook a reconnaissance of the area, recording thickness, cultural evidence, chronology, preservation, relevance and undertaking necessary additional works in five days.

The information presented is derived from geomorphological, stratigraphical, sedimentological and archaeological data collected from the study area and using a standard geoarchaeological fieldwork approach: geomorphological survey and generation of a detailed map using GIS, followed by field description of the sedimentary deposits. Since the archaeological layer was identified as a Pleistocene colluvial 


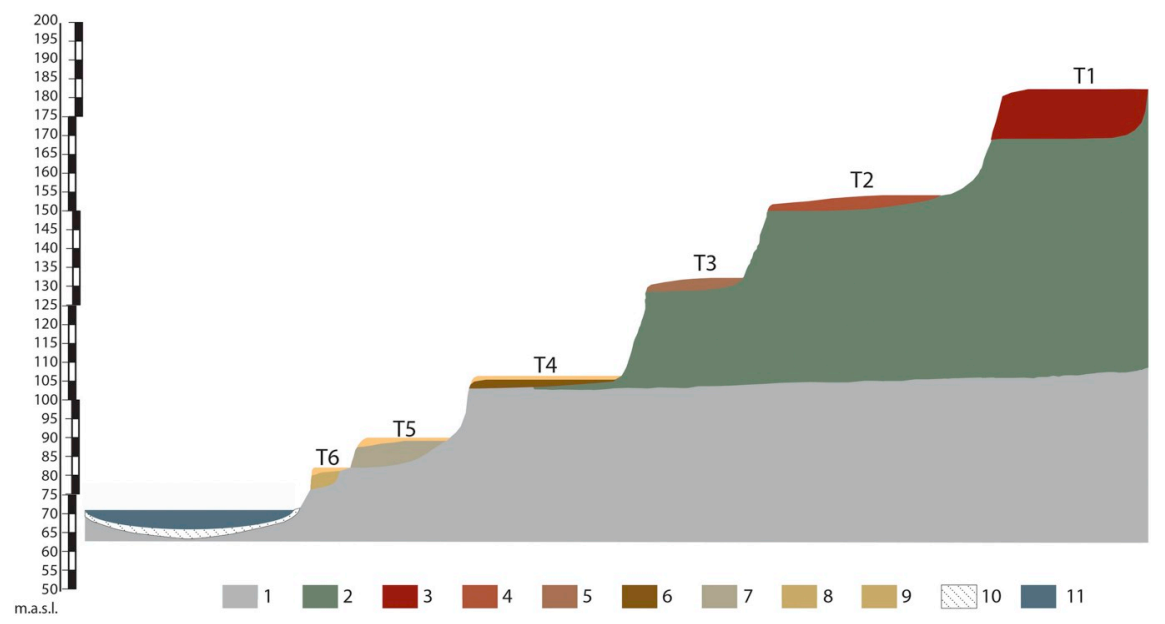

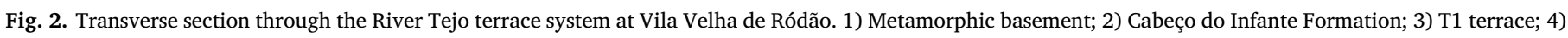
T2 terrace; 5) T3 terrace; 6) T4 terrace; 7) T5 terrace; 8) T6 terrace; 9) Aeolian sands; 10) Sedimentary river bed; 11- Tejo River.

Table 1

Mineral identification in the $<2 \mu \mathrm{m}$ fraction of the studied samples. S) Smectite; I) Illite; K) Kaolinite.

\begin{tabular}{lcccc}
\hline Sampled level & Smectite & Illite & Kaolinite & Clay association \\
\hline Layer 1 & $37 \%$ & $45 \%$ & $18 \%$ & I S k \\
Layer 2 & $57 \%$ & $30 \%$ & $13 \%$ & S I k \\
Layer 3 top & $47 \%$ & $32 \%$ & $21 \%$ & S I k \\
Layer 3 base & $0 \%$ & $47 \%$ & $53 \%$ & K I \\
Layer 4 & $0 \%$ & $66 \%$ & $34 \%$ & I k \\
Layer 5 & $89 \%$ & $4 \%$ & $7 \%$ & S k i \\
\hline
\end{tabular}

unit resulting from the degradation of the T3 terrace, most of the geological data were obtained from primary field observations (geomorphological, stratigraphical and sedimentological). In addition, sediment samples were collected for sedimentological analyses (texture and composition); samples were not collected for luminescence dating, because complete bleaching before deposition could not be guaranteed.

\subsection{Field methods}

For horizontal control, an alphanumeric grid of $10 \times 10 \mathrm{~m}$ was established, covering $3500 \mathrm{~m}^{2}$. To verify the existence of small implements a $1 \mathrm{~m}$ radius around each intersection of the grid was subjected to surface collection. For stratigraphical control, a trench $45 \mathrm{~m}$ long $\times 2 \mathrm{~m}$ wide $\times 2.5-1 \mathrm{~m}$ deep was mechanically excavated to expose the sequence down to the bedrock; in addition, another stratigraphical profile was exposed by the construction activity (Figs. 3d and $4 \mathrm{a}$ to c). Since the entire surface was covered with lithic artefacts and rock debris (Fig. 5a), four manual test pits were excavated (Test pit $1-2 \times 1 \mathrm{~m}$ adjacent to the trench was obliterated by rain; Test pit $2=2 \times 1 \mathrm{~m}$, Test pit $3 \times 3 \mathrm{~m}$; Test pit $42 \times 2 \mathrm{~m}$ ) to observe any layers that may occur with discrete sedimentary differences that could not be recognized during the mechanical work (Fig. 5b to d). The sediments from these test pits were wet-sieved using a $5 \mathrm{~mm}$ mesh and samples were taken for laboratory analysis.

Since it was impossible to perform a manual excavation of the entire area and unacceptable to discard the major volume of sediment with archaeological remains, it was agreed to excavate the archaeological layer mechanically in the richest $1600 \mathrm{~m}^{2}$, using a toothless bucket to ensure a cleaner cut, and following the grid. The sediments were transported to an adjacent area, square by square. Each truck carried a sheet with the alphanumeric code of each square and the sediments were deposited separately. After this, the entire area was bulldozed for the construction. Four people, using two $2 \times 1 \mathrm{~m}$ stainless steel screens with $15 \mathrm{~mm}$ mesh, wet-sieved all the sediments over a period of three months. The mesh size was chosen due to the predominant gravel component. Finally, 10 litres of $<15 \mathrm{~mm}$ gravel was sampled from the screened sediments of each square to recover and estimate the total number of chips (Paixão et al., 2016; Pereira et al., 2015a, 2015c).

Given the disturbance and of the shallow deposit we did not collect samples for pollen and other micro-residues as these are likely to have been contaminated by modern elements and it was unlikely that they could preserve elements with relevance for reconstructing the palaeoenvironment.

\subsection{Sedimentary analysis}

Due to the quantity and size of the clasts, and the overall conditions under which the fieldwork was carried out, these were described in the field in terms of the lithology and shape. Six sedimentary samples of 6 litres each (Layer 1, Layer 2, Layer 3, top, Layer 3 base, Layer 4 colluvial unit - and Layer 5 - substratum; Cabeço do Infante Formation) were collected for determination of clay-mineral composition in order to understand the genesis of the deposit and the palaeoenvironment associated with its formation. These were the most important aspects of site formation to be understood, as they would provide knowledge of whether the artefacts were transported from somewhere else or if they were in their original geomorphological position.

The sediment samples arrived wet at the Centre for Marine and Environmental Research - CIMA, University of Algarve. Samples were thinly spread on brown paper sheets and described macroscopically. Then they were quartered twice to ensure randomness for the collection of subsamples for freeze-drying at room temperature to dehydrate them without using a kiln, in order to avoid chemical alteration. Since each sample had numerous clay aggregates, they were disaggregated mechanically in a ball mill. Then the $<63 \mu \mathrm{m}$ fraction was sent to the Department of Earth Sciences of the University of Coimbra (Laboratory of Sedimentology) for determination of the clay-mineral composition.

The mineralogical composition of the sand fraction was estimated by observation using a Wild mod. Heerbrugg 84,220 stereoscopic binocular microscope $(50 \times)$. The mineralogical composition of the $<2 \mu \mathrm{m}$ fraction was obtained by $\mathrm{X}$-ray diffraction of oriented samples, before and after treatment with ethylene glycol and heating to $550^{\circ} \mathrm{C}$. A Philips PW 3710 X-ray diffractometer was used, with a $\mathrm{Cu}$ tube, at $40 \mathrm{KV}$ and $20 \mathrm{n} \AA$, and the software APD 3.6J-Automatic Powder Diffraction (Philips). The percentages of clay minerals in each sample were determined through the peak areas of the mineral present, with the use of specific correction parameters. 


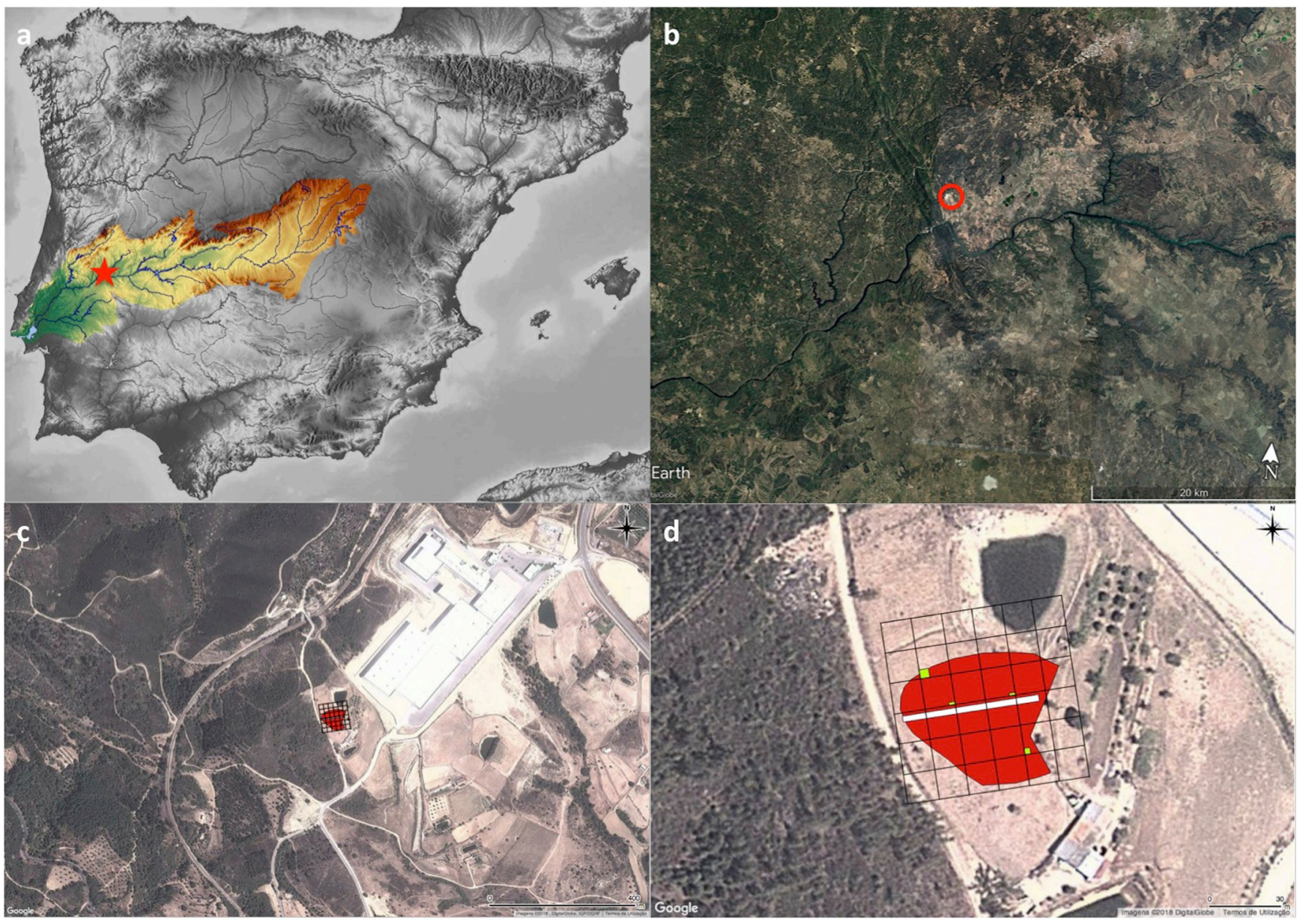

Fig. 3. Location of Cobrinhos: (a) in the Iberian Peninsula and in the basin of the River Tejo; (b) In Lower Tejo reach I; (c) In relation to the factory before being amplified towards west; (d) Concentration area of artefacts (red) manual test pits (green) and trench (white). Aerial photographs extracted from Google Earth. Google and Google logo are registered trademarks of Google Inc.

\subsection{Analysis of lithic artefacts}

The archaeological assemblage from Cobrinhos was studied following standard technological (Benito del Rey and Benito Álvarez, 1998; Boëda, 1994, 1993; Boëda et al., 1990; Bourguignon, 1997; Mourre, 2003; Tixier et al., 1980) and typological criteria (Bordes, 1961). Retouch was only considered when patina was congruent with the rest of the artefact. The data were input in an Access file using the E4 interface (http://www.oldstoneage.com/software/e4.shtml).

The Cobrinhos assemblage is composed solely of lithic artefacts. To avoid misinterpretation, only implements showing clear evidence of knapping were collected. Fire-cracking was searched for but not found. The total inventory is 15,779 specimens but, for the purpose of characterizing the site, 16 squares were sampled, which provided a total of 5543 artefacts, corresponding to $35.1 \%$ of the total. An extensive study of the entire assemblage will be presented elsewhere in the near future.

\section{Results}

\subsection{Characterization of the colluvial unit}

The Cobrinhos colluvial unit is at an altitude of $130-120 \mathrm{~m}$ that links, towards the south, to the $\mathrm{N} 4$ erosive surface (a "glacis"/ramp at an altitude of 120 to $109 \mathrm{~m}$ ) that correspondingly links to the surface of the T4 terrace (Fig. 6).

The colluvial unit overlies, with an erosive contact (discordance), the Cabeço do Infante Formation, which is $>20 \mathrm{~m}$-thick and has a greyish yellow colour (Munsell 2.5 y6.2). The colluvium is 15 to $75 \mathrm{~cm}$ thick, is composed of sub-angular quartzite $(\sim 75-80 \%)$ pebbles and cobbles and milky quartz $(\sim 20-25 \%)$ pebbles, and has the following stratigraphic sequence (from top to base):

Layer 1: 15-25 cm-thick. Present in the entire area. Ploughed. Sandy-silt matrix, reddish brown colour when wet (Munsell 7.5 YR3.4). High clay component, leading the sediment to be plastic and easily moulded when wet. Some clay agglomerates have small stems and fossil roots in a light coloured sandy matrix (deferruginized). Some clay agglomerates have concentrations of iron oxides in their cores. The layer is dominated by a poorly sorted gravel of sub-angular quartzite pebbles and cobbles, but also, in much less quantity, milky quartz pebbles. Organic material varies between dark carbonaceous particles and readily identifiable plant remains. Abundant Mousterian artefacts, which are slightly patinated.

Layer 2: 20 to $30 \mathrm{~cm}$-thick. Does not occur in the western sector of the study area. Ploughed. Plastic clay agglomerates more common towards the bottom. Presence of small plant elements. Sandy-silt matrix highly rich in iron oxides with dull reddish brown colour (Munsell 2.5 YR4.4). Poorly sorted quartzite (predominant) and quartz gravel of sub-angular clasts. Abundant Mousterian artefacts, slightly patinated.

- Layer 3: $20 \mathrm{~cm}$ to $1 \mathrm{~m}$-thick, depending on location. Silt-clay matrix, dark reddish brown colour (Munsell 2.5 YR3.4). Poorly sorted gravel, containing sub-angular clasts of quartzite (predominant) and quartz. It has small nodules of plastic white clay. Lacks 


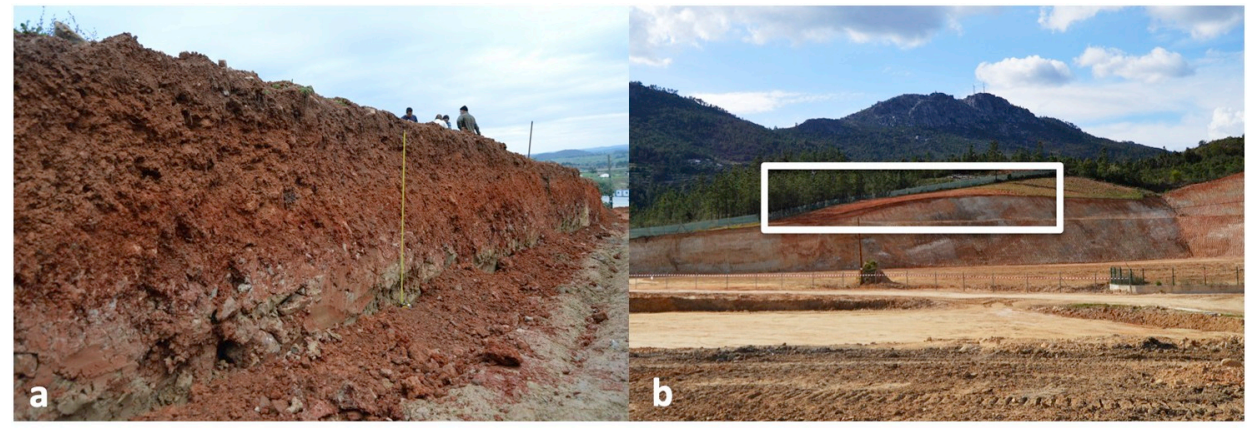

$$
\text { C }
$$

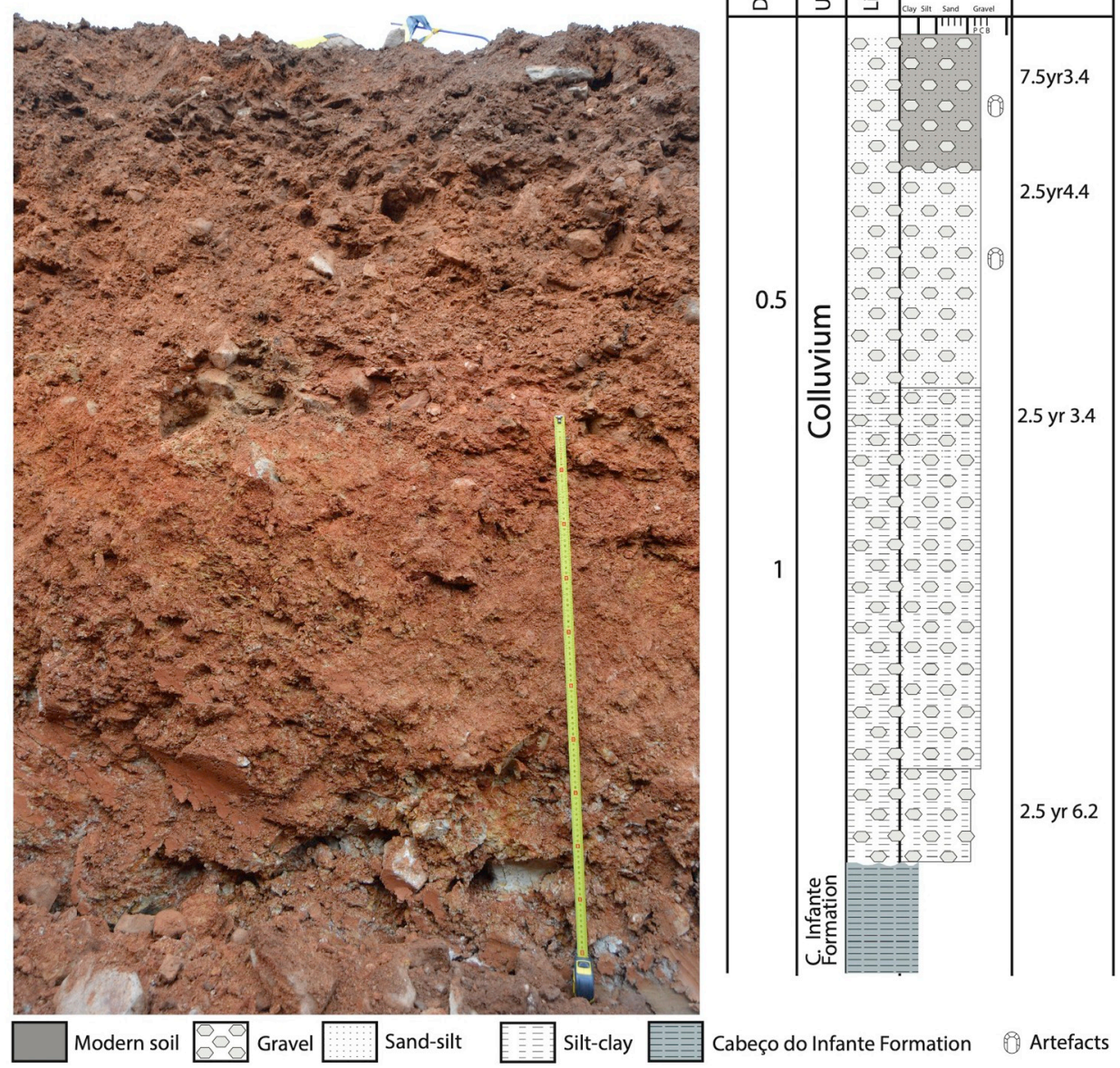

Fig. 4. Profiles at Cobrinhos: (a) trench; (b) cut made by the construction works; (c) Geological log along with a detail of a section of the trench.

archaeological material.

- Layer 4: $15 \mathrm{~cm}$ thick. Poorly sorted gravel, comprising sub-angular clasts of quartzite (predominant) and quartz. Silt-clay matrix, with greyish red colour (Munsell 2.5 YR6.2). Some intraclasts of whitish arkose, from the Palaeogene substratum, can be found. Lacks archaeological material.

- Layer 5: Bedrock. Cabeço do Infante Formation.

The mineralogical composition of the $<2 \mu \mathrm{m}$ fraction, obtained by XRD, indicates that Layer 1, Layer 2 and Layer 3 top have similar proportions of smectite, ilite and kaolinite. Layer 3 base and Layer 4 do not have smectite and have similar values of ilite and kaolinite, while Layer 5 (Cabeço do Infante Formation) is almost exclusively composed of smectite (Table 1 and Supplementary Information 2). That is, smectite is predominant in the substratum, but the colluvial unit layers are dominated by the association of ilite and kaolinite. The
Palaeoweathering that affects this old colluvial unit, i.e., rubification due to the presence of goethite and a clay mineral association of illite and kaolinite, is identical to that typical of the higher terraces, indicating a warm temperate climate with very strong seasonal contrast. This means that the colluvial unit was fed by a deposit located in a higher position on the slope (the T3 terrace) and not by the erosion of the Cabeço do Infante Formation that is underlying it.

\subsection{Archaeological assemblage}

Within a total area of ca. $48,000 \mathrm{~m}^{2}$, the archaeological finds (Fig. 7) were concentrated in about ca. $1600 \mathrm{~m}^{2}$. The assemblage was clearly congruent with Mousterian, there being no artefacts typical of any other period: the implements were only slightly patinated and there was a large abundance of artefacts $<3 \mathrm{~cm}$ as well as implements of several tens of centimeters, suggesting a good preservation of the site 


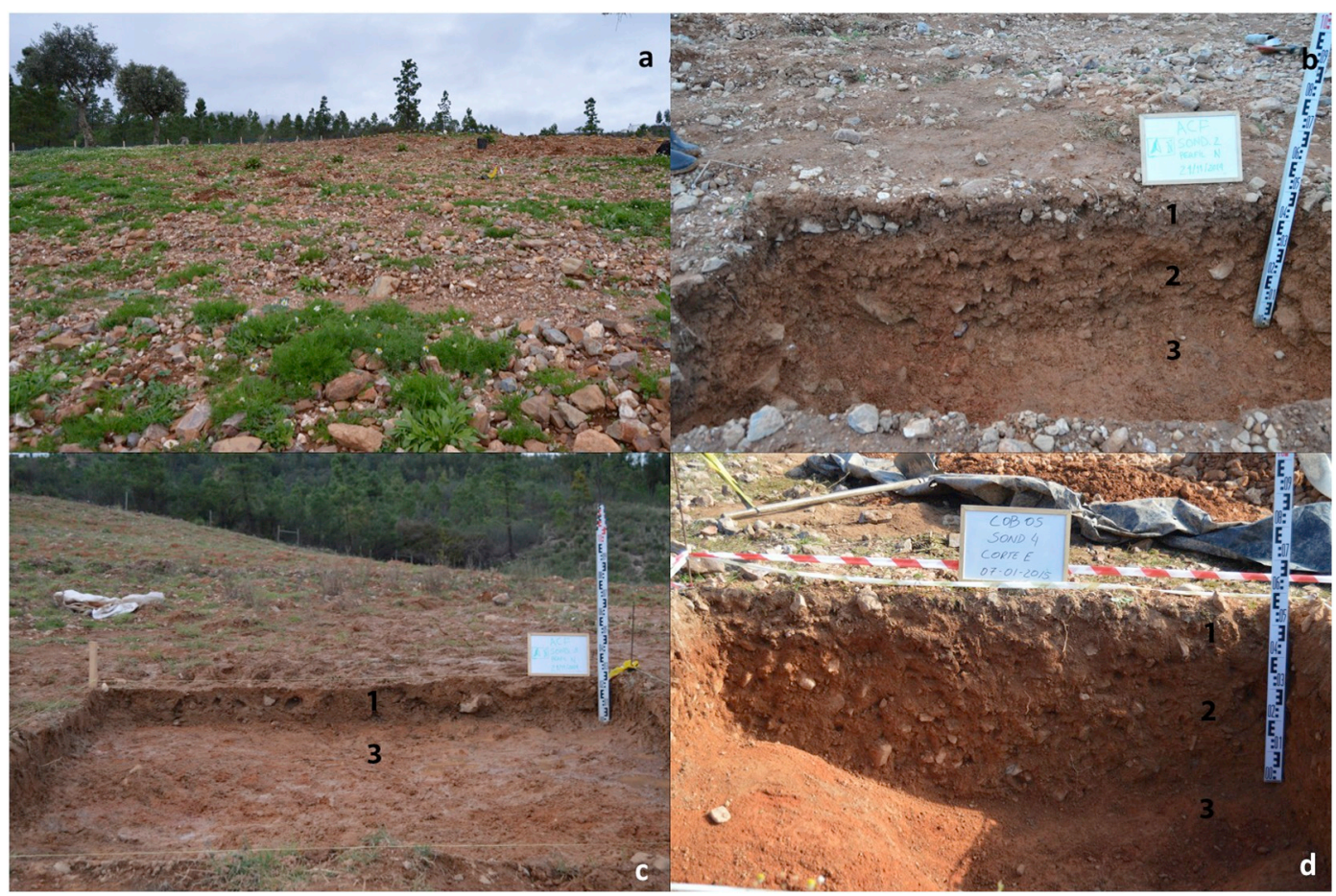

Fig. 5. Cobrinhos. Archaeological context with the natural layers. (a) Surface; (b) test pit 2; (c) test pit 3; (d) test pit 4 . Test pit 2 was obliterated due to rain.

despite the obvious disturbance.

The raw material of the lithic assemblage is dominated by quartzite (91.1\%), of which $8.1 \%$ is a black fine-grained variety, along with milky quartz (8.8\%) and other local rocks (0.05\%) Many artefacts are coated with red clay, this often being almost impossible to remove.

Flakes are the most common artefacts $(60 \%)$, followed by chips $(28.0 \%)$ and fragments $(12.3 \%)$; preparation and maintenance products make up to $1.6 \%$. Blades $(1 \%)$ and points $(0.3 \%)$ occur only in small numbers (Table 2).

Cores have been made on pebbles (84\%) and flakes (11.3\%). The reduction strategies are discoidal (21.6\%), informal (18.3\%), Levallois recurrent (15.5\%), centripetal (11.7\%), chopper/chopping-tool (11.3\%), prismatic (9.9\%), Levallois preferential (8.4\%) and polyhedral (3.3\%). Most cores were abandoned without evident reason (67.1\%) but others were abandoned due to loss of volume (15.5\%), knapping defects $(13.1 \%)$ or raw material problems $(4.2 \%)$ (Fig. 8). The morphology of the nodules is sub-rounded to rounded, with thin and poorly developed cortex (Supplementary Information 1: Table 2).

Blanks are mostly complete $(75.9 \%)$. The paucity of mesial fractions may be related to the difficulty in recognizing these in the context. Cortex is absent in $64.9 \%$ of the blanks and $16.5 \%$ have $<30 \%$. In the blanks, cortex is located on one side laterally $(26.5 \%)$, distally $(24.2 \%)$ or on one side and on the distal $(20.0 \%)$ or proximal (17.6\%) ends. Sections are triangular (36.2\%), plain (29.0\%), trapezoidal (15.6\%) and irregular (15.5\%). Their shapes are irregular (35.1\%) biconvex (20.0\%), concave-convex $(19.2 \%)$ or divergent (13.6\%). Profiles are mostly straight $(80.5 \%)$. Dorsal patterns are typically unidirectional $(33.8 \%)$, crossed $(32-0 \%)$ and centripetal $(10.8 \%)$. Distal ends are stepped $(29.5 \%)$, feathered $(29.0 \%)$ or hinged $(20.7 \%)$, while platforms are plain $(50.1 \%)$, dihedral $(13.2 \%)$, faceted $(12.7 \%)$ or cortical (11.6\%) (Supplementary Information 2: Table 2). The blank: core ratio is 9.3 and, despite some larger artefacts, the general blank assemblage comprises implements with dimensions $20-50 \times 20-45 \times 8-15 \mathrm{~mm}$ (Fig. 9). Kombewa cores and flakes are also present in small numbers and with small dimensions (Table 2 and Supplementary Information 1: Table 3).

The tool assemblage is composed of sidescrapers (24.1\%), Levallois blanks (23.6\%), retouched flakes (13.8\%), denticulates (11.6\%), pseudo-Levallois points (10.5\%) and notches (9.4\%). There is no artefact typical of the Acheulean or of any subdivision of the Upper Palaeolithic (Table 3).

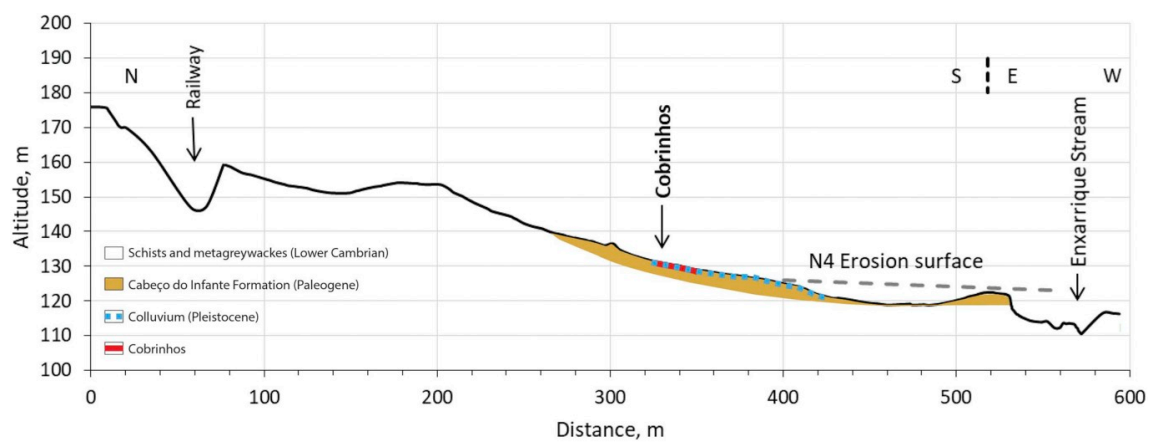

Fig. 6. Cobrinhos. Profile made using GPS-RTK showing schists and metagreywackes (Lower Cambrian) bedrock, Cabeço do Infante Formation (Paleogene), the N4 erosion surface, the colluvial unit (Pleistocene) and the Cobrinhos site. 


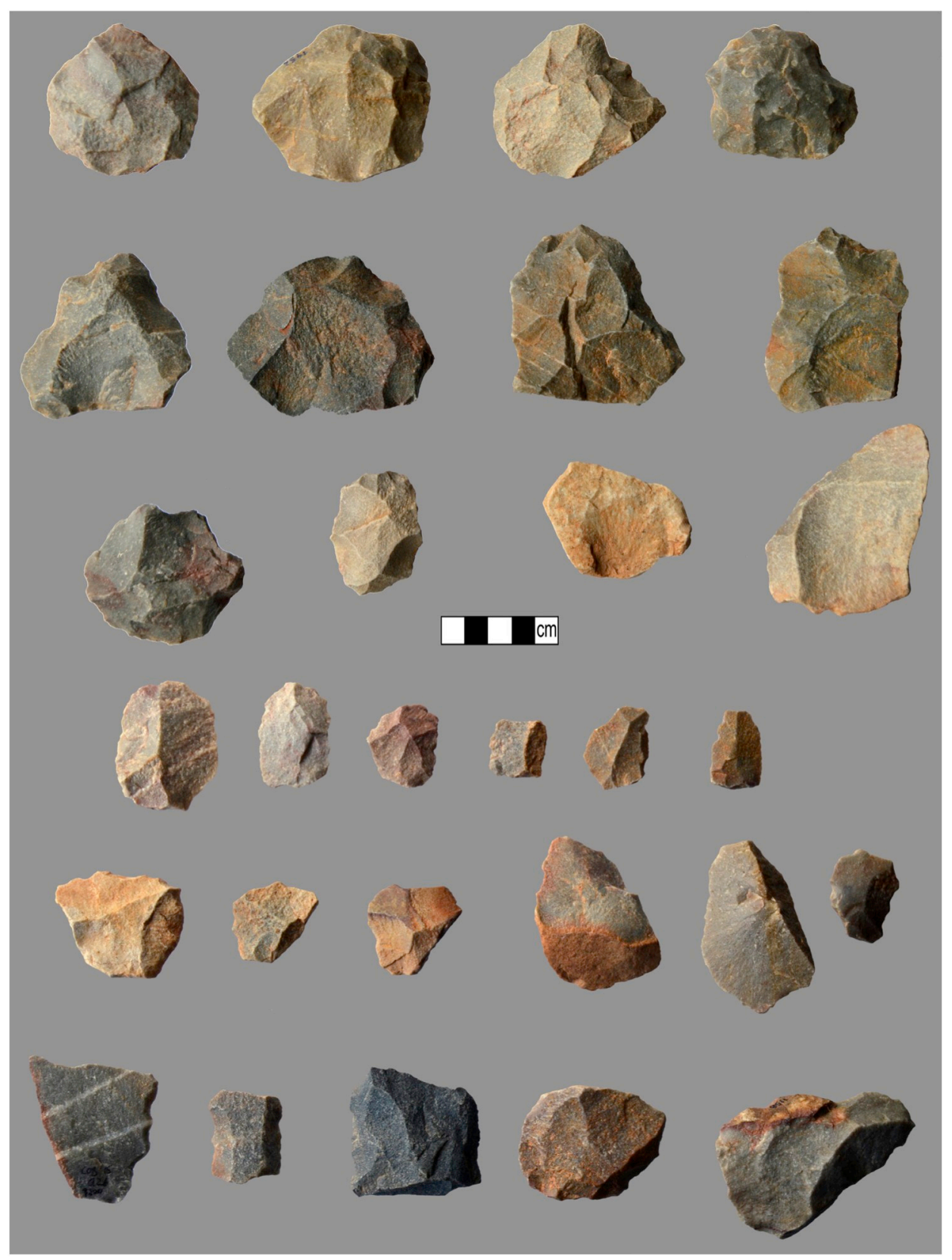

Fig. 7. Cobrinhos. Lithic assemblage. Levallois recurrent, Levallois preferential, discoidal, centripetal, Kombewa cores, Levallois flakes, pseudo-Levallois points, denticulates, notches and sidescrapers.

\section{Discussion}

\subsection{The geological context of the Cobrinhos assemblage}

By integrating archaeological, geomorphological and sedimentological data it is possible to explain the formation of the context at Cobrinhos. Despite it being clearly ploughed, this combination of data offers crucial clues about the formation processes of the site. The assemblage was limited in area and thickness, with a wide range of sizes, including chips. There is an absence of local memory about land use other than growing olive trees, so it is possible that the human occupation level(s) were buried and protected until ploughing in 2014, which may have displaced the lithic artefacts throughout the upper ca. $40 \mathrm{~cm}$ (which is the range of the plough). It would otherwise be expected that the site would have been found previously by any research team working in Ródão during the last 40 years or by the Cultural
Research Management teams working for the factory project. If previously exposed, it would also be expected that the assemblage would show some sorting, but the only signal in the lithic material is from the patina, which is congruent with water percolation, a normal trait considering the shallow context and the open-air setting. Finally, the implements have a wide range of sizes and shapes and all phases of reduction sequences are represented. The only elements that are underrepresented are implements $<1.5 \mathrm{~cm}$ (very small flakes and chips), due to the excavation conditions. Indeed, the uneven distribution of the artefacts on the surface and with no concentration towards the slope may suggest they could be just a few tens of $\mathrm{cm}$ from their original position (Supplementary information 1: Table 4).

In contrast with other sites where water-worn pebbles were the preferential raw material for knapping, the Cobrinhos assemblage was made on material derived directly from the erosion of the massive quartzite outcrops that dominate the study area and spread angular 
Table 2

Cobrinhos. General inventory.

\begin{tabular}{|c|c|c|c|c|c|c|}
\hline \multicolumn{2}{|c|}{$\begin{array}{l}\text { Technological category/raw } \\
\text { material }\end{array}$} & \multirow[t]{3}{*}{ Other } & \multirow{2}{*}{$\begin{array}{c}\text { Quartzite } \\
1\end{array}$} & \multirow[t]{3}{*}{$\begin{array}{l}\text { Black } \\
\text { quartzite }\end{array}$} & \multirow[t]{3}{*}{ Quartz } & \multirow{2}{*}{$\begin{array}{c}\text { Total } \\
1\end{array}$} \\
\hline Blocks & Pebble & & & & & \\
\hline & Nodule & & 2 & & & 2 \\
\hline \multirow[t]{4}{*}{ Debitage } & Core & & 193 & 15 & 5 & 213 \\
\hline & Flake & 3 & 2431 & 346 & 46 & 2826 \\
\hline & Blade & & 50 & 3 & & 53 \\
\hline & Point & & 13 & 2 & & 15 \\
\hline \multirow[t]{5}{*}{ Maintenance } & Cornice & & 12 & 1 & & 13 \\
\hline & Crest & & 6 & & & 6 \\
\hline & Debordant & & 18 & 3 & & 21 \\
\hline & Flank & & 11 & 3 & & 14 \\
\hline & Core front & & 42 & 4 & 1 & 47 \\
\hline \multirow[t]{4}{*}{ Debris } & Fragment & & 592 & 61 & 27 & 680 \\
\hline & $\begin{array}{l}\text { Core } \\
\text { fragment }\end{array}$ & & 82 & 10 & 6 & 98 \\
\hline & Chip & & 1149 & 1 & 404 & 1554 \\
\hline & Total & 3 & 4602 & 449 & 489 & 5543 \\
\hline
\end{tabular}

quartzite material across the landscape, which does not, therefore, have a well-developed cortex. This is the cause of the overall low frequency of cortex. The low blank-to-core ratio contrasts with the intensive reduction of some cores, which suggests that blanks were exported, implying that the site functioned as a quarry, which is also the impression that arises from its overall setting. Nevertheless, the occurrence of complete Levallois blanks and the diversity of tools suggest that it might have had other purposes, such as hunting and/or butchery. Since the site sits over a dense quartzite gravel, the retouched tools must have been intended products, probably related to specific human activities, and not the result of 'Distance Decay' (Renfrew, 2001) or Frison effect (Dibble, 1987), as these are related to the increase of retouch with curation of raw materials and artefacts with increasing distance from raw material sources. Unfortunately, the non-preservation of faunal remains prevents corroboration of these inferences. In summary, the lithic assemblage is fully consistent with a Mousterian industry without any Acheulean influence or Upper Palaeolithic contamination and, therefore, its age must be younger than the closing of Aroeira cave (ca. $280 \mathrm{ka}$ ) and older than the earliest Upper Palaeolithic (ca. 35-32 ka).

The large number of lithic artefacts does not fit with interpretation as a single/short occupation, as documented at other Mousterian sites (Vilas Ruivas, in the study area; Praia Rei Cortiço and Mira Nascente, on the western central Portuguese coast), but probably represents multiple occupations. Despite the conditions under which it was found and excavated, Cobrinhos does not differ significantly from any other European open-air Palaeolithic site on the surface of a Pleistocene terrace with readily available fluvial bedload material of lithologies suitable for stone-tool production (Chlachula and Chlachula, 2014). In fact, because the assemblage does not come from surface collection but from extensive wet-sieved sediments, it is not significantly biased (only for implements $<15 \mathrm{~mm}$ ) and, therefore, it is a reliable case study for
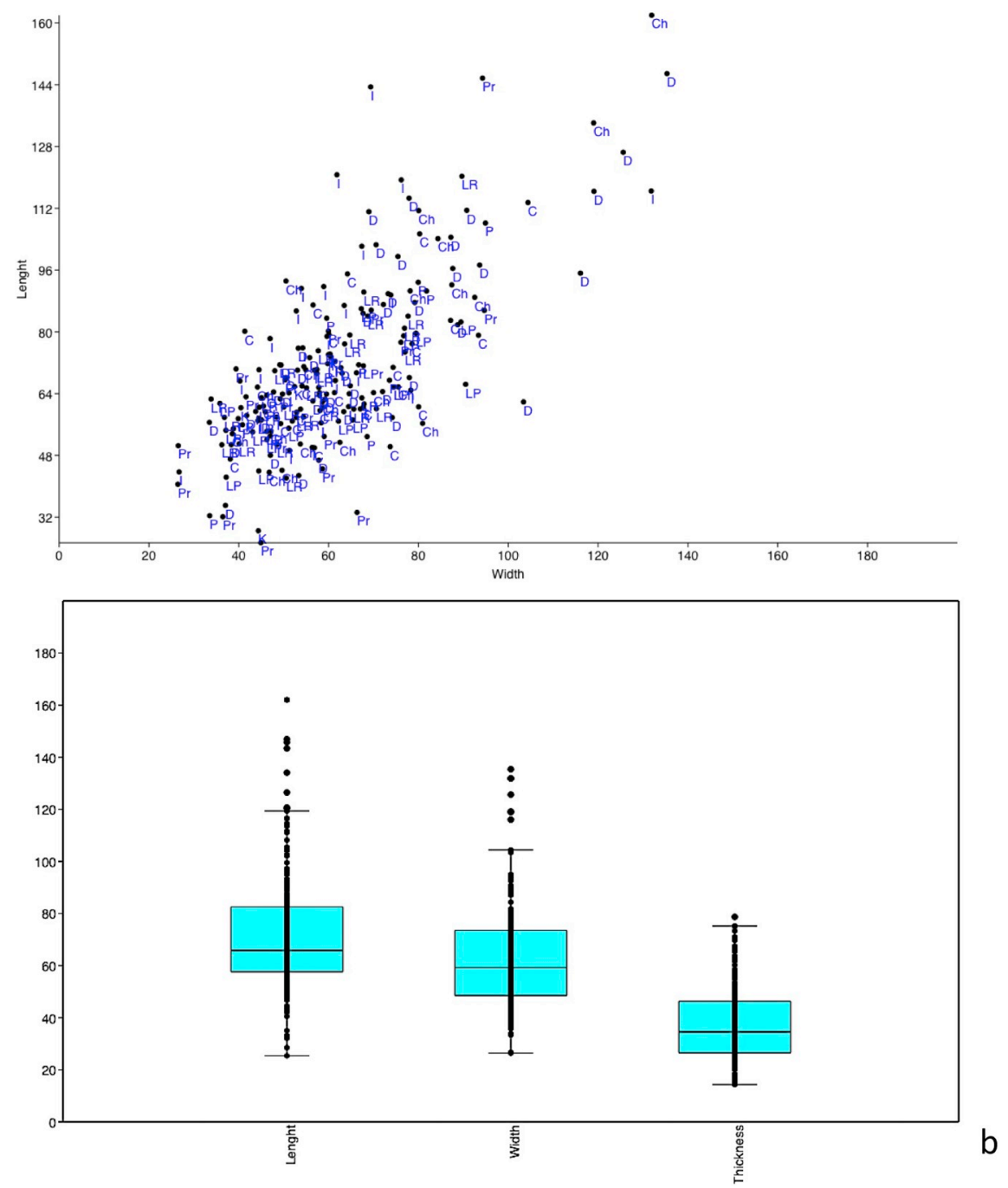

Fig. 8. Cobrinhos. Complete blanks. (a) Plot of length and width of the complete blanks; (b) box and jitter plot of length, width and thickness in millimetre. 

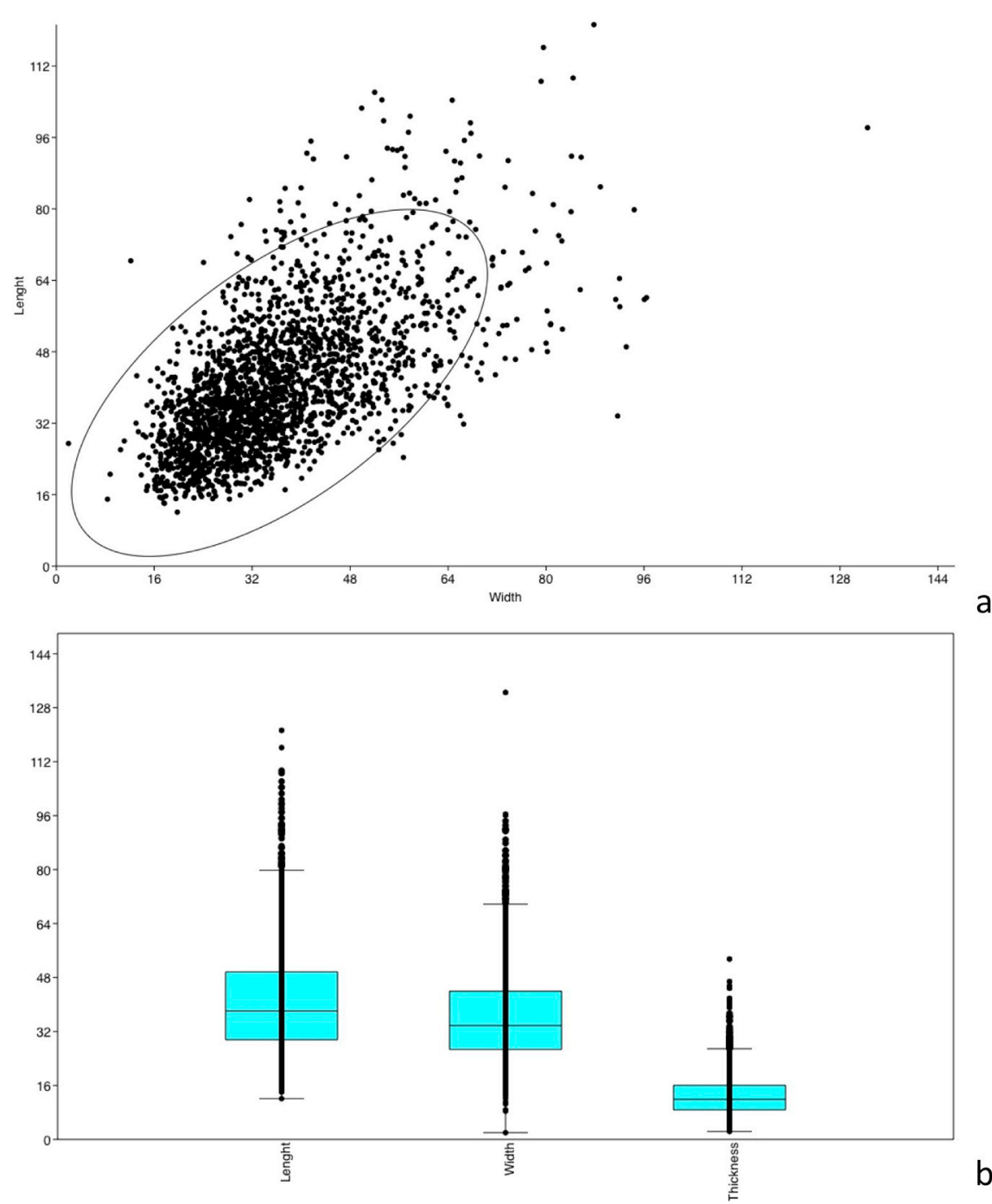

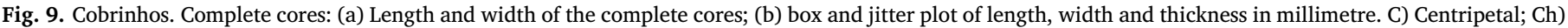
Chopper/Chopping-tool; D) Discoidal; I) Informal; K) Kombewa; LP) Levallois preferential; LR) Levallois recurrent; P) Polyhedral; Pr) Prismatic.

the Mousterian. However, more detailed presentation of the lithic assemblage is necessary to improve knowledge of the technological processes.

As previously observed, the ancient colluvial unit at Cobrinhos, with its associated Mousterian industry, is developed at an altitude of $130-120 \mathrm{~m}$ and links with a ramp (a "glacis", the N4 valley-edge surface) that connects with the T4 terrace at Ródão (at $120 \mathrm{~m}$ altitude). This deposit has the same sediment and weathering characteristics as the top of the T4 sequence and differs from T5 and T6, implying that the environment in which it was formed must pre-date ca. $135 \mathrm{ka}$. This geomorphological setting implies that, despite the difficulty of getting reliable absolute dates for the archaeological deposit, the Cobrinhos industry probably has an age congruent with the topmost deposits of the T4 terrace: at least $155 \mathrm{ka}$ and probably $\geq 170 \mathrm{ka}$. Based on this, the possible age range is ca. $200-155 \mathrm{ka}$ and the most probable age is between ca. 165 and 155 ka.

Since Pleistocene human remains from Portugal can be directly related with lithic industries, with earlier Middle Pleistocene human forms occurring with Acheulean, Neanderthals with Mousterian and modern humans with Upper Palaeolithic (Daura et al., 2017; Duarte et al., 2002; Trinkaus et al., 2011, 2003, 2001; Trinkaus and Maki, 2007; Trinkaus and Zilhão, 2002), the implication is that Cobrinhos represents a Neanderthal occupation.

The abundance of Mousterian sites in the Lower Tejo suggests that it was an attractive location, potentially with better conditions for occupation than other regions (Dennell et al., 2011; González-Sampériz et al., 2010; Rodrigues et al., 2011; Voelker et al., 2017). It may also have worked as a preferential pathway between different landscapes. Unfortunately, detailed comparison between sites, especially in connection with sources of raw material, the technology and typology of the lithic assemblages and the geomorphological and stratigraphical setting, is very difficult because most have never been studied in detail. For the few that have, the comparison is still very difficult because approaches were very different according to the protocols used by different teams.

\subsection{The Middle Palaeolithic in westernmost Iberia}

In central Portugal, evidence from the Aroeira cave indicates that the Mousterian was not yet established by ca. 280 ka (Daura et al., 2018; Hoffmann et al., 2013) or by ca. 201 ka (Cunha et al., 2017b). Typical Mousterian occurs throughout the sequence of Oliveira Cave but along with larger blanks, cleavers and handaxes until ca. 91-61 ka (Deschamps and Zilhão, 2018; Hoffmann et al., 2013; Richter et al., 2014; Zilhão et al., 2013), which is congruent with the material from Milharós, from a colluvial unit above T4 sediments (Raposo, 1996; Raposo et al., 1993), including exquisite handaxes, dated as younger than 155 ka (Cunha et al., 2017b; Raposo, 1996; Raposo et al., 1993). 
Table 3

Cobrinhos. Tool-type list.

\begin{tabular}{|c|c|c|c|c|c|c|}
\hline Type/raw material & Greywacke & Quartzite & Black quartzite & Quartz & Flint & Total \\
\hline 1 Typical Levallois flake & & 27 & 6 & & & 33 \\
\hline 2 Atypical Levallois flake & & 38 & 6 & & & 44 \\
\hline 3 Levallois point & & 4 & 1 & & & 5 \\
\hline 4 Retouched Levallois point & & 1 & & & & 1 \\
\hline 5 Pseudo-Levallois point & & 32 & 5 & & & 37 \\
\hline 6 Mousterian point & & 2 & & & & 2 \\
\hline 8 Limace & 1 & & & & & 1 \\
\hline 9 Single straight sidescraper & & 9 & 3 & & & 12 \\
\hline 10 Single convexe sidescraper & & 26 & 6 & & & 32 \\
\hline 11 Single concave sidescraper & & 10 & 1 & & & 11 \\
\hline 12 Double straight sidescraper & & 2 & & & & 2 \\
\hline 13 Double straight-convex sidescraper & & 4 & & & & 4 \\
\hline 15 Double biconvex sidescraper & & 1 & & & & 1 \\
\hline 16 Double biconcave sidescraper & & 1 & & & & 1 \\
\hline 17 Double concave-convex sidescraper & & 3 & 1 & & & 4 \\
\hline 21 Déjeté sidescraper & & 1 & & & & 1 \\
\hline 22 Transverse straight sidescraper & & 4 & 4 & & & 8 \\
\hline 23 Transverse convex sidescraper & & 3 & 1 & & & 4 \\
\hline 25 Plain face sidescraper & & 1 & 1 & & & 2 \\
\hline 26 Abrupt sidescraper & & 2 & 2 & & & 4 \\
\hline 29 Sidescraper with alternate retouch & & 1 & 1 & & & 2 \\
\hline 34 Typical perforator & & 1 & 1 & & 1 & 3 \\
\hline 36 Backed Knife & & 2 & & & & 2 \\
\hline 38 Natural Backed Knife & & 9 & 3 & & & 12 \\
\hline 39 Mousterian Raclette & & 1 & & & & 1 \\
\hline 40 Mousterian tranchet & & & 2 & & & 2 \\
\hline 41 Truncation & & 7 & & & & 7 \\
\hline 42 Notch & & 27 & 1 & 1 & & 29 \\
\hline 43 Denticulate & & 35 & 5 & & & 40 \\
\hline 45 Flake with ventral retouch & & 31 & 1 & 1 & & 33 \\
\hline 46 Thick Flake with abrupt retouch & & 4 & 1 & & & 5 \\
\hline 47 Thick Flake with alternate retouch & & 2 & & & & 2 \\
\hline 48 Thin Flake with abrupt retouch & & 4 & & & & 4 \\
\hline 49 Thin Flake with alternate retouch & & 2 & & & & 2 \\
\hline 54 Distally notch & & 3 & 2 & & & 5 \\
\hline 56 Rabot & & 1 & & & & 1 \\
\hline 61 Chopping-tool & & 7 & & & & 7 \\
\hline Total & 1 & 308 & 54 & 2 & 1 & 366 \\
\hline
\end{tabular}

Other sites in the Lower Tejo indicate that Mousterian without Acheulean influence was already established when the uppermost deposits of T4 were formed. This is documented by the Atalaia football field site ( $\geq 170 \mathrm{ka}$ ) (Martins et al., 2010b) and Pegos do Tejo 2 ( $>135 \mathrm{ka}$ ) (Almeida et al., 2007). In this last case, a patinated handaxe was reused, as is shown by the presence of retouch cutting the patinated surface (Almeida, 2014).

Typical Mousterian without Acheulean or Upper Palaeolithic influence, that is, Levallois and discoidal technology with centripetal and knapped pebbles, Levallois and pseudo-Levallois blanks, notches, denticulates and sidescrapers, occurs at many terrace sites of the Lower River Tejo with ages similar to or younger than the base of T5 (135 ka) and the sequence of T6 (younger than $32 \mathrm{ka}$ ). These include Caminho da Celulose (Cunha et al., 2008; G.E.P.P., 1977), Vilas Ruivas (Cunha et al., 2008; Raposo, 1995), Ribeira da Atalaia -T5 top (Cura, 2014; Rosa, 2013; Rosina et al., 2014), Estrada do Prado (Mateus, 1984), Santa Cita (Bicho and Ferring Reid, 2001; Lussu et al., 2001), Conceição (Raposo and Cardoso, 1998) and Santo Antão do Tojal (Cunha et al., 2017b; Raposo, 1995), Campo de Futebol de Santo Antão do Tojal (Figueiredo et al., 2005), Azinhal and Tapada do Montinho (Almeida, 2014, 2013; Almeida et al., 2007; Cunha et al., 2017b, 2017a, 2016), and Foz do Enxarrique (Berruti et al., 2016; Cardoso, 1993; Cunha et al., 2008; Martins et al., 2010a; Raposo, 1995; Raposo et al., 1985; Raposo and Brugal, 1999).

The coastal sedimentary sequences of western central Portugal, particularly at Praia Rei Cortiço (ca. $101 \mathrm{ka}$ ) and Mira Nascente (ca. 40 ka) (Benedetti et al., 2009; Cabral et al., 2018; Haws et al., 2009), also contain Mousterian without Acheulean or Upper Palaeolithic influence. This is the same pattern as found in caves such as Columbeira
(Cardoso et al., 2002; Pereira et al., 2015b), possibly dating from between ca. 101 ka and 39 ka (Zilhão et al., 2011), Caldeirão (> 31 ka) (Zilhão, 1997, 1993, 1992), Escoural (ca. 49 ka) (Zilhão and D'Errico, 2000), Figueira Brava (ca. 45 to $31 \mathrm{ka}$ ) (Antunes, 1992; Cardoso and Raposo, 1995). A single handaxe was found in Furninha cave at the base of the succession, although it does not seem to be related to the upper Mousterian levels (Bicho and Cardoso, 2010; Breuil and Zbyszewski, 1945; Cardoso, 1993; Delgado, 1884). There are reports of other sites with smaller assemblages and/or a need for further detailed description, such as Salemas (ca. 32 ka) (Antunes et al., 1989; Raposo, 1995).

\section{Conclusions}

Despite the recent anthropogenic disturbance of the site, the following can be summarized about Cobrinhos: (1) The assemblage is not pristine but it is in its original geomorphological/geological context, which corresponds with a valley-margin colluvial unit; (2) the colluvial unit (resulting from the degradation of the T3 terrace) and associated artefacts are coeval with the deposition of the uppermost deposits of the T4 terrace (with a possible age range of ca. 200-155 ka and most probable age between ca. 165 and $155 \mathrm{ka}$ ); (3) the assemblage has internal coherence and is consistent with a Mousterian industry without Acheulean influence. The large number of artefacts and the depth of distribution suggest that multiple occupations are represented.

Data from Reach I of the Lower Tejo thus indicate that Acheulean was still present at Milharós at 201 ka but Middle Palaeolithic industries, and coeval occupation by Neanderthals, were already established by ca. 200-165 ka, with full Mousterian technology and without 
Acheulean influence. This industry persisted in the study area until ca. $34 \mathrm{ka}$. The Upper Palaeolithic is only encountered after $32 \mathrm{ka}$, in association with a cover unit of aeolian sands.

Considering the ages for both the Acheulean and the Mousterian, the probable age of the Lower to Middle Palaeolithic transition in westernmost Iberia (Portugal) is here proposed as between ca. 200 and $180 \mathrm{ka}$, although this needs to be supported by improved geochronology.

\section{Acknowledgments}

We thank the Associação para o Estudo do Alto Tejo, Vila Velha de Rodão municipality, AMS-BR, SA and Direcção Regional Cultura Centro for their effort towards finding the best solution for this project. Pereira was funded by the project IF/01075/2013, from FCT (Fundação para a Ciência e a Tecnologia). This work was co-funded by FCT - Fundação para a Ciência e Tecnologia, with FEDER - Fundo Europeu de Desenvolvimento Regional and COMPETE 2020 funds, through projects UID/MAR/04292/2019 - MARE (Marine and Environmental Sciences Centre) and UID/GEO/04683/2019 — ICT.

\section{Conflict of interest statement}

On behalf of all authors, the corresponding author states that there is no conflict of interest.

\section{Appendix A. Supplementary data}

Supplementary data to this article can be found online at https:// doi.org/10.1016/j.jasrep.2018.11.026.

\section{References}

Adler, D.S., Wilkinson, K.N., Blockley, S., Mark, D.F., Pinhasi, R., Schmidt-Magee, B.A., Nahapetyan, S., Mallol, C., Berna, F., Glauberman, P.J., Raczynski-Henk, Y., Wales, N., Frahm, E., Jöris, O., MacLeod, A., Smith, V.C., Cullen, V.L., Gasparian, B., 2014. Early Levallois technology and the Lower to Middle Paleolithic transition in the Southern Caucasus. Science 345, 1609-1613. https://doi.org/10.1126/science. 1256484. (80-.).

Albergaria, J., 2014. Ampliação da Unidade Industrial AMS - BR Star Paper, S.A. (Vila Velha de Ródão) - Relatório de Trabalhos Arqueológicos - Descritor Património Estudo de Impacte Ambiental. Lisboa.

Almeida, N.A.C, 2013. Estruturas de habitat do final do Plistocénico Médio em Portugal: o caso dos Pegos do Tejo 2, Portas de Ródão, Nisa. In: Arqueologia Em Portugal - 150 Anos. Associação dos Arqueólogos Portugueses, Lisboa, pp. 243-250.

Almeida, N.A.C., 2014. O Paleolítico Médio das Portas de Ródão, a margem esquerda (Nisa, Portugal). Contributo para a sua caracterização cronoestratigráfica. Universidade de Évora.

Almeida, N.A.C., Deprez, S., De Dapper, M., 2007. As ocupações paleolíticas no nordeste alentejano: uma aproximação geoarqueológica. Rev. Port. Arqueol. 10, 7-16.

Álvarez-Alonso, D., 2014. First neanderthal settlements in northern Iberia: the Acheulean and the emergence of Mousterian technology in the Cantabrian region. Quat. Int. 326-327, 288-306. https://doi.org/10.1016/j.quaint.2012.12.023.

Antunes, M.T., 1992. O Homem da Gruta da Figueira Brava (ca. 30000 BP). Contexto ecológico, alimentação, canibalismo. In: Memórias da Acad. das Ciências Lisboa XXXI, pp. 487-536.

Antunes, M.T., Cabral, J.M.P., Pais, J., Soares, A.M., 1989. Paleolítico Médio e Superior em Portugal: datas 14C, estado actual dos conhecimentos, síntese e discussão. Ciências Terra 10 (10), 127-138.

Arsuaga Ferreras, P.M., Aguirre Enríquez, E., 1979. Rinocerontes lanudos en la provincia de Madrid (Coelodonta antiquitatis Blumenbach). Boletín Real Soc. Española Hist. Nat. Sección Geológica 77, 23-59.

Benedetti, M.M., Haws, J.A., Funk, C.L., Daniels, J.M., Hesp, P.A., Bicho, N.F., Minckley, T.A., Ellwood, B.B., Forman, S.L., 2009. Late Pleistocene raised beaches of coastal Estremadura, central Portugal. Quat. Sci. Rev. 28, 3428-3447. https://doi.org/10. 1016/j.quascirev.2009.09.029.

Benito del Rey, L., Benito Álvarez, J.L., 1998. Métodos y materias instrumentales en Prehistoria y Arqueología (La Edad de la Piedra tallada más antigua) - II. Tecnología y tipología. [Librería Cervantes], Madrid.

Berger, G.W., Pérez-González, A., Carbonell, E., Arsuaga, J.L., Bermúdez de Castro, J.M., Ku, T.L., 2008. Luminescence chronology of cave sediments at the Atapuerca paleoanthropological site, Spain. J. Hum. Evol. 55, 300-311. https://doi.org/10.1016/ j.jhevol.2008.02.012.

Berruti, G.L.F., Rosina, P., Raposo, L., 2016. The use-wear analysis of the quartzite lithic assemblage from the Middle Palaeolithic site of Foz do Enxarrique (Ródão,
Portugal) > Mediterr. Archaeol. Archaeom. 16, 107-126. https://doi.org/10.5281/ zenodo.160961.

Bicho, N.F., Cardoso, L., 2010. Paleolithic occupations and lithic assemblages from Furninha Cave, Peniche (Portugal) Ocupaciones paleolíticas e industrias líticas de la Gruta Furninha, Peniche (Portugal). Zephyrus LXVI, 17-38.

Bicho, N.F. Ferring Reid, C., 2001. O sítio arqueológico de Santa Cita, Tomar, as intervenções arqueológicas de 1990 a 1997. In: Territorios, Mobilidade e Povoamento No Alto Ribatejo II - Santa Cita e o Quaternário Da Região, pp. 71-88.

Bicho, N.F., Hockett, B., Haws, J., Belcher, W., 2000. Hunter-gatherer subsistence at the end of the Pleistocene: Preliminary results from Picareiro Cave, Central Portugal. Antiquity 74, 500-506.

Bicho, N., Marreiros, J., Cascalheira, J., Pereira, T., Haws, J., 2015. Bayesian modeling and the chronology of the Portuguese Gravettian. Quat. Int. 359-360. https://doi. org/10.1016/j.quaint.2014.04.040.

Boëda, É., 1993. Le débitage discoïde et le débitage Levallois récurrent centripède. Bull. Société préhistorique française 90, 392-404. https://doi.org/10.3406/bspf.1993. 9669.

Boëda, É., 1994. Le concept Levallois: variabilité des méthodes, Monographie du CRA. CNRS.

Boëda, É., Geneste, J.-M., Meignen, L., 1990. Identification de chaînes opératoires lithiques du Paléolithique ancien et moyen. Paléo 2, 43-80. https://doi.org/10.3406/pal. 1990.988.

Bordes, F., 1953. Levalloisien et Moustérien. Bull. Société préhistorique Fr. 4, 226-235. https://doi.org/10.3406/bspf.1953.3035.

Bordes, F., 1961. Typologie du Paléololithique ancien et moyen. CNRS, Paris.

Bordes, F., 1971. Observations sur L'Acheuleen des grottes en Dordogne. Munibe 23, $5-23$.

Bordes, F., 1980. Le débitage Levallois et ses variantes. Bull. Société préhistorique française 77, 45-49. https://doi.org/10.3406/bspf.1980.5242.

Bourguignon, L., 1997. Le Moustérien de type Quina: Nouvelle définition d'une entité technique. Dr. en Lettres Sci. Hum. spécialité préhistoire. Université Paris X-Nanterre.

Bradtmöller, M., Pastoors, A., Weninger, B., Weniger, G.-C.C., 2012. The repeated replacement model - rapid climate change and population dynamics in Late Pleistocene Europe. Quat. Int. 247, 38-49. https://doi.org/10.1016/j.quaint.2010.10.015.

Breuil, H., Zbyszewski, G., 1945. Contribution à l'étude des industries paléolithiques du Portugal et de leurs rapports avec la géologie du Quaternaire: les principaux gisements des plages quaternaires du littoral d'Estremadura et des terrasses fluviales de la basse vallée du Tage. Comun. dos Serviços Geológicos Port 26, 1-679.

Bridgland, D.R., 2000. River terrace systems in north-west Europe: an archive of environmental change, uplift and early human occupation. Quat. Sci. Rev. 19, 1293-1303. https://doi.org/10.1016/S0277-3791(99)00095-5.

Bridgland, D.R., Maddy, D., 2002. Global correlation of long Quaternary fluvial sequences: a review of baseline knowledge and possible methods and criteria for establishing a database. Neth. J. Geosci. 81, 265-281. https://doi.org/10.1017/ S0016774600022605.

Bridgland, D., Westaway, R., 2008. Climatically controlled river terrace staircases: a worldwide Quaternary phenomenon. Geomorphology 98, 285-315. https://doi.org/ 10.1016/J.GEOMORPH.2006.12.032.

Bridgland, D.R., White, M.J., 2014. Fluvial archives as a framework for the Lower and Middle Palaeolithic: patterns of British artefact distribution and potential chronological implications. Boreas 43, 543-555. https://doi.org/10.1111/bor.12059.

Bridgland, D.R., Harding, P., Allen, P., Candy, I., Cherry, C., George, W., Horne, D.J., Keen, D.H., Penkman, K.E.H., Preece, R.C., Rhodes, E.J., Scaife, R., Schreve, D.C., Schwenninger, J.-L., Slipper, I., Ward, G.R., White, M.J., White, T.S., Whittaker, J.E., 2013. An enhanced record of MIS 9 environments, geochronology and geoarchaeology: data from construction of the high speed 1 (London-Channel tunnel) raillink and other recent investigations at Purfleet, Essex. UK. Proc. Geol. Assoc. 124, 417-476. https://doi.org/10.1016/J.PGEOLA.2012.03.006.

Cabral, J., Ribeiro, P., Ramos, A., Cunha, P.P., 2018. Diapiric activity affecting Late Pliocene to Pleistocene sediments under a tectonic compressive regime: an example from the Western Iberian Margin ( $\mathrm{Sr}^{\mathrm{a}}$ da Vitória beach, central Portugal). J. Iber. Geol. 1-15. https://doi.org/10.1007/s41513-018-0073-3.

Cardoso, J.L., 1993. Contribuição para o conhecimento dos grandes mamíferos do Plistocénico Superior de Portugal. Câmara Municipal de Oeiras, Oeiras.

Cardoso, J.L., Raposo, L., 1995. As indústrias paleolíticas da Gruta da Figueira Brava (Setúbal). In: Actas Da 3 Reunião Do Quaternário Ibérico, pp. 451-456.

Cardoso, J.L., Raposo, L., Veiga Ferreira, O., 2002. A Gruta Nova da Columbeira, Bombarral. Câmara Municipal do Bombarral, Bombarral.

Carmignani, L., Moncel, M.H.E., Fernandes, P., Wilson, L., 2017. Technological variability during the Early Middle Palaeolithic in Western Europe. Reduction systems and predetermined products at the Bau de l'Aubesier and Payre (South-East France). PLoS One 12, e0178550. https://doi.org/10.1371/journal.pone.0178550.

Cartailhac, E., 1886. Les âges préhistoriques de I'Espagne et du Portugal. C. Reinwald, Paris.

Carvalho, L., 2014. Relatório de acompanhamento arqueológico da construção da Fábrica de Papel AMS Papermill and Converting, SA (Vila Velha de Ródão). (Soure).

Chauhan, P.R., Bridgland, D.R., Moncel, M.H., Antoine, P., Bahain, J.J., Briant, R., Cunha, P.P., Despriée, J., Limondin-Lozouet, N., Locht, J.L., Martins, A.A., Schreve, D.C., Shaw, A.D., Voinchet, P., Westaway, R., White, M.J., White, T.S., 2017. Fluvial deposits as an archive of early human activity: Progress during the 20 years of the Fluvial Archives Group. Quat. Sci. Rev. 166, 114-149. https://doi.org/10.1016/j. quascirev.2017.03.016.

Chlachula, J., Chlachula, R., 2014. Geoarchaeology of the Middle Palaeolithic locality at Znojmo, southern Moravia. Quat. Int. 326-327, 168-183. https://doi.org/10.1016/j. quaint.2013.12.021.

Choffat, P., 1884. Conclusions sur la Commission chargé de l'examen des silex trouvés à 
Otta. In: Congrés International d'Anthropologie et d'Archéologie Préhistoriques. C.-R. Geme Session (Lisbonne, 1880). Typographie de l'Académie Royale des Sciences, Lisbonne, pp. 92-118.

Corrêa, A.A.M., 1926. O Homem Terciário em Portugal. Lusit. - Rev. Estud. Port. 3, 1-16. Corrêa, A.A.M., 1928. Nouvelles recherches sur l'homme tertiaire en Portugal. In: Actas Da III Sessão Do Congresso Internacional de Ciências Pré-Históricas e Proto-Históricas (Amsterdam, 1927). Librairie E. Nourry, Paris, pp. 1-5.

Costa, F.A.P., 1865. Da existencia do Homem em epochas remotas no valle do Tejo. Primeiro opusculo. Noticia sobre os esqueletos humanos descobertos no Cabeço da Arruda. Imprensa Nacional, Lisboa.

Cunha, P.P., 1992. Estratigrafia e sedimentologia dos depósitos do Cretácio Superior e Terciário de Portugal central, a leste de Coimbra. Universidade Coimbra.

Cunha, P.P., 1996. Unidades litostratigráficas do Terciário da Beira Baixa. Comun. Inst. Geológico Min. 82, 87-130.

Cunha, P.P., Martins, A.A., 2000. Transição do enchimento terciário para o encaixe fluvial quaternário, na área de Vila Velha de Ródão (sector NE da Bacia do Baixo Tejo). Ciências da Terra 14, 173-184.

Cunha, P.P., Martins, A.A., 2004. Principais aspectos geomorfológicos de Portugal central, sua relação com o registo sedimentar e a relevante importância do controlo tectónico. In: Geomorfol ogia do Noroeste da Península Ibérica, pp. 151-178.

Cunha, P.P., Barbosa, B.P., Pena, R., Reis, D., 1993. Synthesis of the Piacenzian onshore record between the Aveiro and Setubal parallels (Western portuguese margin). Ciencias Terra 12, 35-43.

Cunha, P.P., Martins, A.A., Huot, S., Murray, A.S., Raposo, L., 2008. Dating the Tejo river lower terraces in the Ródão area (Portugal) to assess the role of tectonics and uplift. Geomorphology 102, 43-54. https://doi.org/10.1016/j.geomorph.2007.05.019.

Cunha, P.P., Almeida, N.A.C., Aubry, T., Martins, A.A., Murray, A.S., Buylaert, J.P., Sohbati, R., Raposo, L., Rocha, L., 2012. Records of human occupation from Pleistocene river terrace and aeolian sediments in the Arneiro depression (Lower Tejo River, central eastern Portugal). Geomorphology 165-166, 78-90. https://doi.org/ 10.1016/j.geomorph.2012.02.017.

Cunha, P.P., Martins, A.A., Gouveia, M.P., 2016. The terrace staircases of the lower Tagus river (Ródão to Chamusca) - characterization and interpretation of the sedimentary, tectonic, climatic and palaeolithic data. Estud. Quat. 14, 1-24.

Cunha, P.P., Cura, S., Cunha Ribeiro, J.P., Figueiredo, S., Martins, A.A., Raposo, L., Pereira, T., Almeida, N.A.C., 2017a. As indústrias do Paleolítico Inferior e Médio associadas ao Terraço T4 do Baixo Tejo (Portugal central) - arquivos da mais antiga ocupação humana no oeste da Ibéria, com ca. 340 ka a 155 ka. J. Lithic Stud. 4, 1-25. https://doi.org/10.2218/jls.v4i2.xxx.

Cunha, P.P., Martins, A.A., Buylaert, J.P., Murray, A.S., Raposo, L., Mozzi, P., Stokes, M., 2017b. New data on the chronology of the Vale do Forno sedimentary sequence (Lower Tejo River terrace staircase) and its relevance as a fluvial archive of the Middle Pleistocene in western Iberia. Quat. Sci. Rev. 166, 204-226. https://doi.org/ 10.1016/j.quascirev.2016.11.001.

Cura, S., 2014. Tecnologia lítica e comportamento humano no pleistocénico Médio final do Alto Ribatejo: Estudo da indústria lítica da Ribeira da Ponte da Pedra. Universidade de Trás-os-Montes e Alto Douro.

da Ferreira, O.V., 1966. Acerca dos primeiros restos de Homo neanderthalensis en contrados no Mustierense de Portugal. Lucerna 5, 361-375.

da Ferreira, O.V., 1984. O mais importante nivel de ocupação do caçador neanderthal da Gruta Nova da Columbeira (Bombarral), in: Volume d'hommage Au Géologue G. Zbyszewski. pp. 365-370.

Daura, J., Sanz, M., Arsuaga, J.L., Hoffmann, D.L., Quam, R.M., Ortega, M.C., Santos, E., Gómez, S., Rubio, Á., Villaescusa, L., Souto, P., Mauricio, J., Rodrigues, F., Ferreira, A., Godinho, P., Trinkaus, E., Zilhão, J., 2017. New Middle Pleistocene hominin cranium from Gruta da Aroeira (Portugal). Proc. Natl. Acad. Sci. 114, 3397-3402. https://doi.org/10.1073/pnas.1619040114.

Daura, J., Deschamps, M., Matias, H., Souto, P., Rodrigues, F., Zilhão, J., 2018. A 400,000-year-old Acheulean assemblage associated with the Aroeira-3 human cranium (Gruta da Aroeira, Almonda karst system, Portugal). Comptes Rendus Palevol. https://doi.org/10.1016/j.crpv.2018.03.003.

Daveau, S., 1980. Espaço e tempo evolução do ambiente geográfico de Portugal ao longo dos tempos pré-históricos. Cliometrica 2, 13-37.

Daveau, S., 1993. Terraços fluviais e litorais. In: de Carvalho, G.S., de B. Ferreira, A., de Senna Martinez, J.C. (Eds.), O Quaternário Em Portugal: Balanço e Perspectivas. Colibri, pp. 17-28.

de la Peña, P., 2013. The beginning of the Upper Paleolithic in the Baetic Mountain area (Spain). Quat. Int. 318, 69-89. https://doi.org/10.1016/j.quaint.2013.08.008.

de la Torre, I., Martínez-Moreno, J., Mora, R., 2013. Change and stasis in the Iberian Middle Paleolithic. Curr. Anthropol. 54, S320-S336. https://doi.org/10.1086/ 673861.

Delgado, J.F.N., 1867. Da existência do homem no nosso solo em tempos mui remotos provada pelos estudos das cavernas. In: Primeiro opúsculo: notícia ácerca das grutas da Cesareda. Lisboa, Comissão Geológica de Portugal.

Delgado, J.F.N., 1884. La Grotte de Furninha a Peniche. In: Congrès International d'Anthropologie et d'Archéologie Préhistoriques. Compte-rendu de La Neuvième Session à Lisbonne (1880). Académie Royale des Sciences, Lisbonne, pp. 207-279.

Delgado, N., 1901. Les silex tertiaires d'Otta. Commun. da Direcção dos Serviços Geológicos Port 4, 161-164.

Dennell, R.W., Martinón-Torres, M., Bermúdez de Castro, J.M., 2011. Hominin variability, climatic instability and population demography in Middle Pleistocene Europe. Quat. Sci. Rev. 30, 1511-1524. https://doi.org/10.1016/J.QUASCIREV.2009.11. 027.

Deschamps, M., Zilhão, J., 2018. Assessing site formation and assemblage integrity through stone tool refitting at Gruta da Oliveira (Almonda karst system, Torres Novas, Portugal): a Middle Paleolithic case study. PLoS One. https://doi.org/10. 1371/journal.pone.0192423.

Dibble, H., 1987. The interpretation of middle paleolithic scraper morfology. Am. Antiq 52, 109-117.

Dibble, H.L., Bar-Yosef, O., 1995. The definition and interpretation of Levallois technology. Monogr. World Archaeol. 502. https://doi.org/10.1002/evan.1360020302.

Duarte, C., Hillson, S.W., Holliday, T.W., Trinkaus, E., 2002. The Lagar Velho I human skeletal inventory. In: Portrait of the Artist as a Child, pp. 221-241.

Falguères, C., Bahain, J.J., Yokoyama, Y., Arsuaga, J.L., Bermudez De Castro, J.M., Carbonell, E., Bischoff, J.L., Dolo, J.M., 1999. Earliest humans in Europe: the age of TD6 gran Dolina, Atapuerca, Spain. J. Hum. Evol. 37, 343-352. https://doi.org/10. 1006/jhev.1999.0326.

Fernández Peris, J., Barciela González, V., Blasco López, R., Cuartero Monteagudo, F., Sañudo Die, P., 2008. El Paleolítico Medio en el territorio valenciano y la variabilidad tecno-económica de la Cova del Bolomor. Treballs d'Arqueologia 14, 141-169.

Figueiredo, S., Carvalho, J., Nobre, L., 2005. A estação arqueológica do Campo de Futebol de Santo Antão do Tojal - Loures. In: O Paleolitico. Actas Do IV Congresso de Arqueologia Peninsular, pp. 349-364.

Finlayson, C., Giles Pacheco, F., Rodríguez-Vidal, J., Fa, D.A., María Gutierrez López, J., Santiago Pérez, A., Finlayson, G., Allue, E., Baena Preysler, J., Cáceres, I., Carrión, J.S., Fernández Jalvo, Y., Gleed-Owen, C.P., Jimenez Espejo, F.J., López, P., Antonio López Sáez, J., Antonio Riquelme Cantal, J., Sánchez Marco, A., Giles Guzman, F., Brown, K., Fuentes, N., Valarino, C.A., Villalpando, A., Stringer, C.B., Martinez Ruiz, F., Sakamoto, T., 2006. Late survival of Neanderthals at the southernmost extreme of Europe. Nature 443, 850-853. https://doi.org/10.1038/nature05195.

Finlayson, C., Fa, D.a., Jiménez Espejo, F., Carrión, J.S., Finlayson, G., Giles Pacheco, F., Rodríguez Vidal, J., Stringer, C., Martínez Ruiz, F., 2008. Gorham's cave, Gibraltar-the persistence of a Neanderthal population. Quat. Int. 181, 64-71. https://doi.org/10.1016/j.quaint.2007.11.016.

G.E.P.P, 1977. O Paleolítico (As primeiras comunidades humanas de caçadores-recolectores). Museu Francisco Tavares Proença Júnior, Castelo Branco.

G.E.P.P, 1980. Vilas Ruivas: um acampamento do Paleolítico Médio. Hist. Soc. 7, 29-33.

G.E.P.P, 1983. A estação Paleolítica de Vilas Ruivas (Ródão). Campanha de 1979. O Arqueólogo Port IV, 15-38.

Galván, B., Hernández, C.M., Mallol, C., Mercier, N., Sistiaga, A., Soler, V., 2014. New evidence of early Neanderthal disappearance in the Iberian Peninsula. J. Hum. Evol. 75, 16-27. https://doi.org/10.1016/J.JHEVOL.2014.06.002.

González-Sampériz, P., Leroy, S.A.G., Carricn, J.S., Fernández, S., García-Anton, M., GilGarcía, M.J., Uzquiano, P., Valero-Garcés, B., Figueiral, I., 2010. Steppes, savannahs, forests and phytodiversity reservoirs during the Pleistocene in the Iberian Peninsula. Rev. Palaeobot. Palynol. 162, 427-457. https://doi.org/10.1016/j.revpalbo.2010.03. 009.

Grimaldi, S., Rosina, P., 2001. O Plistoceno Médio Final do Alto Ribatejo (Portugal central): o sítio da Ribeira da Ponte da Pedra. Ark. Dent. 11, 89-116.

Haws, J.A., Benedetti, M.M., Funk, C.L., Daniels, J.M., Hesp, P.a., Bicho, N.F., Minckley, T.a., Ellwood, B.B., Forman, S.L., 2009. Late Pleistocene raised beaches of coastal Estremadura, central Portugal. Quat. Sci. Rev. 28, 3428-3447. https://doi.org/10 1016/j.quascirev.2009.09.029.

Heleno, M., 1965. Um quarto de século de investigação arqueológica. O Arqueólogo Port. tomo III, 221-237.

Henriques, F., 2015. Relatório final dos trabalhos de acompanhamento arqueológico do Projecto de Alteração e Ampliação da Fábrica de Papel Tissue a AMS BR STAR PAPER, SA em Vila Velha de Ródão. Vila Velha de Ródão.

Hoffmann, D.L., Pike, A.W.G., Wainer, K., Zilhão, J., 2013. New U-series results for the speleogenesis and the Palaeolithic archaeology of the Almonda karstic system (Torres Novas, Portugal). Quat. Int. 294, 168-182. https://doi.org/10.1016/j.quaint.2012 05.027 .

Jacinto, M.J., 2008a. Relatório dos Trabalhos Arqueológicos: Avaliação Ambiental Estratégica: Descritor Património: Área de Expansão da Área Industrial de Vila Velha de Ródão. (Lisboa).

Jacinto, M.J., 2008b. Relatório dos Trabalhos Arqueológicos: Estudo de Impacte Ambiental: Projecto de Execução: Descritor Património: Fábrica de Papel Tissue AMS: Vila Velha de Ródão. (Lisboa).

Jöris, O., Álvarez Fernández, E., Weninger, B., 2003. Radiocarbon evidence of the Middle to Upper Palaeolithic transition in Southwestern Europe. Trab. Prehist. 60, 15-38. https://doi.org/10.3989/tp.2003.v60.i2.79.

Laplana, C., Herráez, E., Yravedra, J., Bárez, S., Rubio, S., Panera, J., Rus, I., PérezGonzález, A., 2015. Biocronología de la terraza compleja de Butarque del río Manzanares en el Estanque de Tormentas al sur de Madrid (España). Estud. Geol. 71, e028. https://doi.org/10.3989/egeol.41808.338.

Lisiecki, L.E., Raymo, M.E., 2005. A Pliocene-Pleistocene stack of 57 globally distributed benthic $\delta 180$ records. Paleoceanography 20,1-17. https://doi.org/10.1029/ 2004 PA001071.

Lobarinhas, D., Rodrigues, J., Brilha, J., Carvalho, C.N., 2010. Inventory of the geological heritage from Portas de Almourão region (Vila Velha de Ródão and Proença-a-Nova, Naturtejo Geopark). Geosciences On-Line Journal 18 (4), 1-4.

Lussu, T., Rosina, P., Oosterbeek, L., Costa, F., 2001. O Musteriense de Santa Cita (Tomar, Alto Ribatejo): investigação e conservação. In: Territorios, Mobilidade e Povoamento No Alto Ribatejo II - Santa Cita e o Quaternário Da Região, pp. 13-70.

Martins, A.A., Cunha, P.P., 2009. Terraços do Rio Tejo em Portugal, sua importância na interpretação da evolução da paisagem e da ocupação humana. Arqueol. do Vale do Tejo 167-178.

Martins, A.A., Cunha, P.P., Huot, S., Murray, A.S., Buylaert, J.P., 2009. Geomorphological correlation of the tectonically displaced Tejo River terraces (Gavião-Chamusca area, central Portugal) supported by luminescence dating. Quat. Int. 199, 75-91. https:// doi.org/10.1016/j.quaint.2009.01.009.

Martins, A.A., Cunha, P.P., Buylaert, J.-P., Huot, S., Murray, A.S., Dinis, P., Stokes, M., 
2010a. K-feldspar IRSL dating of a Pleistocene river terrace staircase sequence of the Lower Tejo River (Portugal, western Iberia). Quat. Geochronol. 5, 176-180. https:// doi.org/10.1016/j.quageo.2009.06.004.

Martins, A.A., Cunha, P.P., Rosina, P., Osterbeek, L., Cura, S., Grimaldi, S., Gomes, J., Buylaert, J.P., Murray, A.S., Matos, J., 2010b. Geoarchaeology of Pleistocene openair sites in the Vila Nova da Barquinha-Santa Cita area (Lower Tejo River basin, central Portugal). Proc. Geol. Assoc. 121, 128-140. https://doi.org/10.1016/j. pgeola.2010.01.005.

Martins, A.A., Cabral, J., Cunha, P.P., Stokes, M., Borges, J., Caldeira, B., Martins, A.C., 2017. Geomorphology tectonic and lithological controls on fluvial landscape development in central-eastern Portugal: insights from long profile tributary stream analyses. Geomorphology 276, 144-163. https://doi.org/10.1016/j.geomorph.2016.10. 012 .

Mateus, J., 1984. Intervenção arqueológica de emergência na estação paleolítica da Estrada do Prado (Tomar). Inf. Arqueol. 4, 158-164.

McPherron, S.P., 1994. A Reduction Model for Variability in Acheulean Biface Morphology. University of Pennsylvania.

Metodiev, D., Romão, J., Dias, R., Ribeiro, A., 2009. Vila Velha de Ródão syncline (Central-Iberian Zone, Portugal): lithostratigraphy, structure and evolutionary model of the Variscan tectonic. Comun. Geológicas 96, 5-18.

Mishra, S., White, M.J., Beaumont, P., Antoine, P., Limondin-Lozouet, N., Santisteban, J.I., Schreve, D.C., Shaw, A.D., Wenban-Smith, F.F., Westaway, R.W.C., White, T.S., 2007. Fluvial deposits as an archive of early human activity. Quat. Sci. Rev. 26, 2996-3016. https://doi.org/10.1016/J.QUASCIREV.2007.06.035.

Mourre, V., 2003. Discoïde ou pas discoïde? Réflexions sur la pertinence des critères techniques définissant le débitage discoïde. In: Peresani, M. (Ed.), Discoid Lithic Technology: Advances and Implications. Archaeopress, Oxford, pp. 1-17.

Ollé, A., Mosquera, M., Rodríguez, X.P., de Lombera-Hermida, A., García-Antón, M.D. García-Medrano, P., Peña, L., Menéndez, L., Navazo, M., Terradillos, M., Bargalló, A., Márquez, B., Sala, R., Carbonell, E., 2013. The Early and Middle Pleistocene technological record from Sierra de Atapuerca (Burgos, Spain). Quat. Int. 295, 138-167. https://doi.org/10.1016/j.quaint.2011.11.009.

Paixão, E., Caninas, J.C., Carvalho, E., Figueiredo, O., Henriques, F., Maio, D., Mendes, C., Nora, D., Pereira, A., Raposo, L., Pereira, T., 2016. The Mousterian site of Cobrinhos, Vila Velha de Ródão (Portugal). In: II Congresso Internacional de Arqueologia Da Região de Castelo Branco. Sociedade dos Amigos do Museu de Francisco Tavares Proença Júnior, Castelo Branco, pp. 135-150.

Panera, J., Torres, T., Pérez-González, A., Ortiz, J.E., Rubio-Jara, S., Uribelarrea del Val, D., 2011. Geocronología de la terraza compleja de Arganda en el valle del Río Jarama (Madrid, España). Estud. Geol. 67, 495-504. https://doi.org/10.3989/egeol.40550. 204.

Panera, J., Rubio-Jara, S., Yravedra, J., Blain, H.A., Sesé, C., Pérez-González, A., 2014. Manzanares valley (Madrid, Spain): a good country for proboscideans and neanderthals. Quat. Int. 326-327, 329-343. https://doi.org/10.1016/j.quaint.2013.09. 009.

Pereira, T., Caninas, J., Carvalho, E., Figueiredo, O., Henriques, F., Maio, D., Mendes, C., Nora, D., Paixão, E., Pereira, A., Raposo, L., 2015a. Cobrinhos, A New Mousterian Site in Vila Velha de Ródão (Portugal). Poster Present. Paleoanthropological Soc, Meet.

Pereira, T., Manso, C., Alves, E., Alves, L.C., Benedetti, M.M., Bicho, N., 2015b. The Neanderthal Cognition: Chert Procurement in SW Iberia Using PIXE Analysis, Poster Presented in the Archaeological Institute of America Meeting.

Pereira, T., Paixão, E., Figueiredo, O., 2015c. Cobrinhos - Relatório Final. (Faro).

Picin, A., Peresani, M., Falguères, C., Gruppioni, G., Bahain, J.J., 2013. San Bernardino cave (Italy) and the appearance of Levallois technology in Europe: results of a radiometric and technological reassessment. PLoS One 8, 4-11. https://doi.org/10. 1371/journal.pone.0076182.

Raposo, L., 1995. Ambientes, territorios y subsistencia en el Paleolítico Medio de Portugal. Complutum 6, 57 (doi).

Raposo, L., 1996. Quartzite bifaces and cleavers in the final Acheulian assemblage of Milharós (Alpiarça, Portugal). In: Non-Flint Stone Tools and the Palaeolithic Occupation of the Iberian Peninsula, pp. 151-165.

Raposo, L., Brugal, J.-P., 1999. Foz do Enxarrique (Ródão, Portugal): preliminary results of the analysis of a bone assemblage from a Middle Palaeolithic open site. In: Gaudzinski, S., Turner, E. (Eds.), The Role of the Early Humans in the Accumulation of European Lower and Middle Palaeolithic Bone Assemblages, Monographien Des Römisch-Germanischen Zentralmuseums, 42. Römisch-Germanischen Zentralmuseums, pp. 367-378.

Raposo, L., Cardoso, J.L., 1998. O Sítio do Paleolítico Médio da Conceição (Alcochete) Lusoponte, Lisboa.

Raposo, L., Cardoso, J.L., 2000. Quadro estratigráfico e cronológico do Quaternário Inferior português e a questão das primeiras indústrias líticas. In: I Jornadas Do Quaternário Da APEQ. Associação Portuguesa para o Estudo do Quaternário (APEQ), Porto.

Raposo, L., Santonja, M., 1995. The earliest occupation of Europe: the Iberian peninsula. In: The Earliest Occupation of Europe. Leiden University Press, pp. 7-25.

Raposo, L., Silva, A.C., 1981. Elementos de cultura material na estação paleolítica de Vilas Ruivas (Ródão). Arqueologia 4, 94-104.

Raposo, L., Silva, A.C., 1982. A campanha de escavações de 1979 em Vilas Ruivas. Inf. Arqueol. 2, 43-48.

Raposo, L., Salvador, M., Silva, A.C., 1985. Notícia da descoberta da estação mustierense da Foz do Enxarrique. In: Actas Da I Reunião Do Quaternário Ibérico. vol 1. Grupo de Trabalho para o Estudo do Quaternário, pp. 79-89.

Raposo, L., Salvador, M., Pereira, J.P., 1993. O Acheulense no Vale do Tejo, em território português. Arqueol. História X 3-29.

Renfrew, C., 2001. From molecular genetics to archaeogenetics. Proc. Natl. Acad. Sci. U. S. A. 98, 4830-4832. https://doi.org/10.1073/pnas.091084198.
Ribeiro, C., 1866. Estudos geologicos. Descripção do solo quaternario das bacias hydrographicas do Tejo e Sado. Commissão Geologica de Portugal, Lisboa.

Ribeiro, C., 1867. Note sur le terrain quaternaire du Portugal. Bull. Société Géologique Fr. 2, 692-717.

Ribeiro, C., 1871. Descripção de alguns silex e quartzites lascados encontrados nas camadas dos terrenos terciario e quaternario da bacias do Tejo e Sado. Academia Real das Sciencias de Lisboa, Lisboa.

Ribeiro, C., 1873a. Sur des silex taillés, découverts dans les terrains miocêne et pliocêne du Portugal. In: Congrês International d'Anthropologie et d'Archéologie Préhistoriques. C-R. 6ême Session (Bruxelles, 1872). C. Muquardt, Bruxelles, Bruxelles, pp. 95-100.

Ribeiro, C., 1873b. Sur la position géologique des couches miocênes et pliocênes du Portugal qui contiennent des silex taillés. In: Congrês International d'Anthropologie et d'Archéologie Préhistoriques. C-R. 6ême Session (Bruxelles, 1872). C. Muquardt, Bruxelles, pp. 100-104.

Ribeiro, C., 1880. L'homme tertiaire au Portugal. In: Congrês International d'Anthropologie et d'Archéologie 53 Préhistoriques. C-R. 9éme Session (Lisbonne, 1880). Typographie de l'Académie Royale des Sciences, Lisbonne, pp. 81-92.

Richter, D., Angelucci, D.E., Dias, M.I., Prudêncio, M.I., Gouveia, M.A., Cardoso, G.J., Burbidge, C.I., Zilhão, J., 2014. Heated flint TL-dating for Gruta da Oliveira (Portugal): Dosimetric challenges and comparison of chronometric data. J. Archaeol. Sci. 41, 705-715. https://doi.org/10.1016/j.jas.2013.09.021.

Roche, J., 1973. Rapport sur les recherches faites dans les grottes du Vale Roto durant l'année. pp. 1973.

Roche, J., da Veiga Ferreira, O., 1970. Stratigraphie et faunes des niveaux paléolithiques de la Grotte de Salemas (Ponte de Lousa). Comun. Serviços Geológicos Port. 54, 263-269.

Roche, J., da Veiga Ferreira, O., Camarate França, J., 1961. Sagaie à base pointue trouvée dans le niveau périgordien de la Grotte de Salemas. Comun. Serviços Geológicos Port. 45, 207-209.

Roche, J., Camarate França, J., da Ferreira, O.V., Zbyszewski, G., 1962. Le Paléolithique Supérieur de la Grotte de Salemas (Ponte de Lousa). Comun. Serviços Geológicos Port. 46, 197-207.

Rodrigues, T., Voelker, A.H.L., Grimalt, J.O., Abrantes, F., Naughton, F., 2011. Iberian margin sea surface temperature during MIS 15 to 9 (580-300 ka): glacial suborbital variability versus interglacial stability. Paleoceanography 26. https://doi.org/10. 1029/2010PA001927.

Rodríguez, X.P., 2004. Atapuerca y el inicio del Paleolítico medio en Europa. Homen. a Emiliano Aguirre. vol IV. pp. 416-431.

Romão, J., 2001. Beiras Group lithostratigraphy in the SW border of the Central-Iberian Zone, Envendos-Barragem do Fratel region (Central Portugal). Comunicações do Instituto Geológico e Mineiro 88, 5-18.

Rosa, L.G., 2013. Approccio tecno-economico all 'analisi delle industrie litiche provenienti dal terrazzo T5 a Ribeira da Atalaia (Portogallo). Instituto Politécnico de Tomar.

Rosina, P., Voinchet, P., Bahain, J.J., Cristovão, J., Falguères, C., 2014. Dating the onset of Lower Tagus River terrace formation using electron spin resonance. J. Quat. Sci. 29, 153-162. https://doi.org/10.1002/jqs.2689.

Rubio-Jara, S., Panera, J., Rodríguez-de-Tembleque, J., Santonja, M., Pérez-González, A. 2016. Large flake Acheulean in the middle of Tagus basin (Spain): middle stretch of the river Tagus valley and lower stretches of the rivers Jarama and Manzanares valleys. Quat. Int. 411, 349-366. https://doi.org/10.1016/j.quaint.2015.12.023.

Santonja, M., Pérez-González, A., 2006. La industria lítica del miembro estratigráfico medio de Ambrona (Soria, España) en el contexto del Paleolítico Antiguo de la Península Ibérica. Zephyrvs 59, 7-20.

Santonja, M., Pérez-González, A., 2010. Mid-Pleistocene Acheulean industrial complex in the Iberian Peninsula. Quat. Int. 223-224, 154-161. https://doi.org/10.1016/j. quaint.2010.02.010.

Santonja, M., Villa, P., 1990. The Lower Paleolithic of Spain and Portugal. J. World Prehist. 4, 45-94. https://doi.org/10.1007/BF00974819.

Santonja, M., Pérez-González, A., Panera, J., Rubio-Jara, S., Méndez-Quintas, E., 2016. The coexistence of Acheulean and Ancient Middle Palaeolithic techno-complexes in the Middle Pleistocene of the Iberian Peninsula. Quat. Int. 411, 367-377. https://doi. org/10.1016/j.quaint.2015.04.056.

Schreve, D.C., Bridgland, D.R., Allen, P., Blackford, J.J., Gleed-Owen, C.P., Griffiths, H.I., Keen, D.H., White, M.J., 2002. Sedimentology, palaeontology and archaeology of late Middle Pleistocene River Thames terrace deposits at Purfleet, Essex, UK. Quat. Sci. Rev. 21, 1423-1464. https://doi.org/10.1016/S0277-3791(01)00100-7.

Silva, P.G., 2003. El Cuaternario del valle inferior del Manzanares (Cuenca de Madrid). Estud. Geol. 59, 107-131.

Silva, A.C., Pimenta, C.M., Lemos, F.S., Mateus, J., Raposo, L., Coutinho, M.J., 1975. O estudo do Paleolitico da área do Ródão. O Arqueólogo Port. 7, 31-47.

Silva, P.G., López-Recio, M., Tapias, F., Roquero, E., Morín, J., Rus, I., Carrasco-García, P., Giner-Robles, J.L., Rodríguez-Pascua, M.A., Pérez-López, R., 2013. Stratigraphy of the Arriaga Palaeolithic sites. Implications for the geomorphological evolution recorded by thickened fluvial sequences within the Manzanares River valley (Madrid Neogene Basin, Central Spain). Geomorphology 196, 138-161. https://doi.org/10. 1016/j.geomorph.2012.10.019.

Silva, P.G., Roquero, E., López-Recio, M., Huerta, P., Martínez-Graña, A.M., 2017. Chronology of fluvial terrace sequences for large Atlantic rivers in the Iberian Peninsula (Upper Tagus and Duero drainage basins, Central Spain). Quat. Sci. Rev. 166, 188-203. https://doi.org/10.1016/j.quascirev.2016.05.027.

Soriano, S., Villa, P., 2017. Early Levallois and the beginning of the Middle Paleolithic in central Italy. PLoS One 12, 1-28. https://doi.org/10.1371/journal.pone.0186082.

Terradillos-Bernal, M., Díez-Fernández-Lomana, J.C., 2012. La transition entre les Modes 2 et 3 en Europe: Le rapport sur les gisements du Plateau Nord (Péninsule Ibérique). 
Anthropologie 116, 348-363. https://doi.org/10.1016/j.anthro.2012.06.001.

Tixier, J., Inizan, M.-L., Roche, H., 1980. Préhistoire de la pierre taillée: Terminologie et technologie. CNRS.

Trinkaus, E., Maki, J., 2007. Middle Paleolithic Human Remains From the Gruta da Oliveira (Torres Novas), Portugal. Am. J. Phys. Anthropol. 273, 263-273. https://doi. $\operatorname{org} / 10.1002 /$ ajpa.

Trinkaus, E., Zilhão, J., 2002. Portrait of the Artist as a Child the Gravettian Human Skeleton from Abrigo Do Lagar Velho and its Archaeological Context, Trabalhos de Arqueologia. Instituto Português de Arqueologia, Lisboa.

Trinkaus, E., Bailey, S.E., Zilhão, J., 2001. Upper Paleolithic human remains from the Gruta do Caldeirão, Tomar. Portugal. Rev. Port. Arqueol. 4, 5-17.

Trinkaus, E., Marks, A.E., Brugal, J.-P., Bailey, S.E., Rink, W.J., Richter, D., 2003. Later Middle Pleistocene human remains from the Almonda Karstic system, Torres Novas, Portugal. J. Hum. Evol. 45, 219-226. https://doi.org/10.1016/j.jhevol.2003.07.001.

Trinkaus, E., Bailey, S.E., Davis, S.J.M., Zilhão, J., 2011. The Magdalenian human remains from the Galeria da Cisterna (Almonda karstic system, Torres Novas, Portugal) and their archeological context. O Arqueólogo Port. Série V 1, 395-413.

Voelker, A., Rodrigues, T., Padilha, M., Jimenez, F.J., 2017. Early to middle Pleistocene climate records off southern Iberia reveal two types of interglacial climate evolution. Geophys. Res. Abstr. EGU Gen. Assem. Dept. Biogeochem. 19, 2017-10456.

Westaway, R., Bridgland, D., White, M., 2006. The Quaternary uplift history of central southern England: evidence from the terraces of the Solent River system and nearby raised beaches. Quat. Sci. Rev. 25, 2212-2250. https://doi.org/10.1016/J. QUASCIREV.2005.06.005.

White, M., Scott, B., Ashton, N., 2006. The Early Middle Palaeolithic in Britain: archaeology, settlement history and human behaviour. J. Quat. Sci. 21, 525-541. https:// doi.org/10.1002/jqs.1034.

Yravedra, J., Rubio-Jara, S., Panera, J., Uribelarrea, D., Pérez-González, A., 2012. Elephants and subsistence. Evidence of the human exploitation of extremely large mammal bones from the Middle Palaeolithic site of PRERESA (Madrid, Spain). J. Archaeol. Sci. 39, 1063-1071. https://doi.org/10.1016/j.jas.2011.12.004.

Zbyszewski, G., 1943. La classificatión du Paléolithique Ancien et la chronologie du Quaternaire au Portugal. Bol. da Soc. Geológica Port. II, 113.

Zbyszewski, G., 1946. Etude géologique de la région d'Alpiarça. Comun. dos Serviços Geológicos Port XXVII, 1-125.

Zbyszewski, G., 1954. Étude geológique de la région de Santarém. Comun. dos Serviços Geológicos Port XXXV, 1-48.

Zbyszewski, G., 1958. Le Quaternaire du Portugal. Bol. da Soc. Geol. Port XIII, 227.

Zbyszewski, G., 1966. Conhecimentos actuais sobre o Paleolítico português. In: Comemoração Do I Centenário Da Associação Dos Arqueólogos Portugueses. II. Associação dos Arqueólogos Portugueses, Lisboa, pp. 109-133.

Zbyszewski, G., 1977. Três ossos de vertebrados quaternarios. Comun. dos Serviços Geológicos Port. 61, 191-194.
Zbyszewski, G., Breuil, H., 1943. Le Quaternaire de Santo Antão do Tojal. Comun. dos Serviços Geológicos Port XXIV, 43-70.

Zbyszewski, G., Roche, J., Camarate França, J., da Veiga Ferreira, O., 1961. Note préliminaire sur les niveaux du Paléolithique supérieur de la grotte de Salemas (Ponte de Lousa). Comun. Serviços Geológicos Port. 45, 197-206.

Zilhão, J., 1992. Gruta do Caldeirão, o Neolítico Antigo. Trabalhos de Arqueologia 6 IPPAR, Lisboa.

Zilhão, J., 1993. Le passage du Paléolithique moyen/Paléolithique supérieur dans le Portugal. In: El Origin Del Hombre Moderno En El Suroeste de Europa, pp. 127-146.

Zilhão, J., 1997. O Paleolítico Superior da Estremadura portuguesa.

Zilhão, J., 2000. The Ebro Frontier: A Model for the Late Extinction of Iberian Neanderthals. In: Neanderthals in the edge150th Anniv. Conf. Forbes' Quarr. Discov. Gibraltar, pp. 111-121. https://doi.org/10.1109/ICELMACH.2008.4800248.

Zilhão, J., 2006. Chronostratigraphy of the Middle-to-Upper Paleolithic Transition in the Iberian Peninsula. Pyrenae 37, 7-84. https://doi.org/10.1039/c4cc09587a.

Zilhão, J., 2009. The Ebro frontier revisited. In: Camps, Marta, Szmidt, Carolyn (Eds.), The Mediterranean from 50000 to 25000 BP: Turning Points and New Directions. Oxbow Books, Oxford, pp. 293-311.

Zilhão, J., D'Errico, F., 2000. La nouvelle bataille aurignacienne B. Une vision critique de la chronologie du Chatelperronien et de l'Aurignacien ancien. Anthropologie 104, 17-50. https://doi.org/10.1016/S0003-5521(00)90002-5.

Zilhão, J., Maurício, J., Souto, P., 1990. A arqueologia da Gruta do Almonda (Torres Novas). Resultados das escavações de 1988-89. In: Actas Das IV Jornadas Arqueológicas, pp. 161-171.

Zilhão, J., Maurício, J., Pedro, S., 1993. Jazidas Arqueológicas do Sistema Cársico da Nascente do Almonda. Nov. Augusta 7, 35-54.

Zilhão, J., Davis, S.J.M., Duarte, C., Soares, A.M.M., Steier, P., Wild, E., 2010. Pego do Diabo (Loures, Portugal): dating the emergence of anatomical modernity in westernmost Eurasia. PLoS One 5, e8880. https://doi.org/10.1371/journal.pone. 0008880 .

Zilhão, J., Cardoso, J.L., Pike, A.W.G., Weninger, B., 2011. Gruta Nova da Columbeira (Bombarral, Portugal): site stratigraphy, age of the Mousterian sequence, and implications for the timing of neanderthal extinction in Iberia. Quartar 58, 93-112.

Zilhão, J., Augelucci, D., Aubry, T., Badal, E., Brugal, J.-P., Carvalho, R., Gameiro, C. Hoffman, D., Matias, H., Maurício, J., Nabais, M., Pike, A., Póvoas, L., Richter, D., Souto, P., Trinkaus, E., Wainer, K., Willman, J., 2013. A Gruta da Oliveira (Torres Novas): Uma jazida de referência para o Paleolítico Médio da Península Ibérica. In: Arqueol. em Port. - 150 Anos. 5. pp. 259-268.

Zilhão, J., Anesin, D., Aubry, T., Badal, E., Cabanes, D., Kehl, M., Klasen, N., Lucena, A., Martín-Lerma, I., Martínez, S., Matias, H., Susini, D., Steier, P., Wild, E.M., Angelucci, D.E., Villaverde, V., Zapata, J., 2017. Precise dating of the Middle-to-Upper Paleolithic transition in Murcia (Spain) supports late Neandertal persistence in Iberia. Heliyon 3, e00435. https://doi.org/10.1016/j.heliyon.2017.e00435. 